\title{
LA INEXISTENCIA JURÍDICA DE LOS ACTOS JURISDICCIONALES ${ }^{1}$
}

\author{
THE VOIDNESS OF JUDICIAL DECISIONS
}

\section{Gabriel Bocksang Hola ${ }^{2}$}

\begin{abstract}
RESUMEN: Este artículo analiza la aplicación de la categoría de la nulidad stricto sensu -es decir, de la inexistencia jurídica- a los actos jurisdiccionales. Ella ha tenido continuidad histórica desde el derecho romano hasta nuestros días, y una presencia reducida pero significativa en el derecho comparado continental, por lo que debería ser recibida con mayor claridad en el derecho chileno como mecanismo de salvaguardia del Estado de Derecho.
\end{abstract}

Palabras clave: Nulidad, inexistencia jurídica, invalidez, acto jurisdiccional, cosa juzgada, imprescriptibilidad.

ABSTRACT: This article analyzes the application of the category of imprescriptible voidness [i.e. "juridical inexistence"] to judicial decisions. It has experienced historical continuity since Roman law to our days, as well as a small but important presence in continental comparative law; therefore, it should be more clearly received in Chilean law as a mechanism of protection of the Rule of Law.

Key words: Voidness, nullity, invalidity, judicial decision, res judicata, imprescriptibility.

\section{INTRODUCCIÓN}

En derecho procesal, la invalidez de los actos jurisdiccionales es comúnmente tratada bajo el manto amplio de las llamadas "nulidades procesales", que abarcan promiscuamente desde irregularidades de aspectos específicos del proceso hasta importantes violaciones al derecho adjetivo que pueden ser perseguidas por recursos como el de casación o el de nulidad.

Debe tenerse presente que dichas nulidades procesales son entendidas casi automáticamente en nuestro régimen jurídico como tipos de invalidez cuyo saneamiento se impone por razones que pueden ser bien diversas: por ejemplo, al no existir un perjuicio reparable solo con la declaración de nulidad ${ }^{3}$, por convalidación ${ }^{4}$, o por cumplimiento de la finalidad del acto respecto de todos los interesados ${ }^{5}$. Y, por cierto, mediante el saneamiento procesal por antonomasia: la autoridad de cosa juzgada adquirida por la sentencia respectiva, institución que impide toda ulterior impugnación a su respecto ${ }^{6}$.

1 El presente artículo forma parte del proyecto de investigación VRI-UC Inicio 33/2011, "La unidad de la nulidad de derecho público", cuyo investigador responsable es el autor.

2 Profesor de Derecho Administrativo, Pontificia Universidad Católica de Chile. Correo electrónico: gbocksan@uc.cl.

3 Código de Procedimiento Civil chileno, art. 83 inciso primero; Código Procesal Penal chileno, art. 159.

4 Código de Procedimiento Civil chileno, art. 83 inciso segundo; Código Procesal Penal chileno, art. 164.

5 Código Procesal Penal chileno, art. 164.

6 Código de Procedimiento Civil chileno, art. 174. 
Atendido el saneamiento antedicho, cabe conceptualizar dogmáticamente a la generalidad de las llamadas "nulidades procesales" como casos de anulabilidad, es decir, el tipo específico de invalidez en que la existencia de un vicio no obsta a la formación del acto jurídico correspondiente, limitándose a habilitar a uno o más titulares a solicitar la destrucción ex post del acto por un cierto lapso. Vencido este, la acción prescribe y el acto se sanea.

Sin embargo, la teoría de los actos jurídicos ha desarrollado una segunda especie de invalidez, la nulidad, del latín nullus, sintetizado a partir de la construcción non ullus que significa "nada" o "nadie" la Antigüedad clásica ${ }^{8}$, recibió a principios del siglo XIX en Francia la denominación de "inexistencia jurídica", a fin de evitar confundirla con la anulabilidad, que empezaba a ser designada de manera prosaica por los autores bajo el vocablo "nullite" ${ }^{\text {" }}$. Sin embargo, en otros países como Italia (nullità), España (nulidad, o nulidad de pleno derecho) y Alemania (Nichtigkeit), el término nulidad siguió designando al concepto nulidad, tal como ha ocurrido en Chile por vía constitucional ${ }^{10}$.

La nulidad, entre otros atributos, se caracteriza por su imprescriptibilidad ${ }^{11}$. Así, en materia de actos jurisdiccionales, la imprescriptibilidad implica que la cosa juzgada no se forme ${ }^{12}$, pues esta -la cosa juzgada- implica la existencia de un momento a partir del cual toda impugnación es irrealizable. Dicha situación no es frecuente, pero tampoco es imposible $^{13}$, lo que es graficado también en Chile por el ámbito de aplicación de la nulidad de derecho público del artículo $7^{\circ}$ de la Constitución, que incluye a los actos jurisdiccionales, como lo hemos anticipado en otro trabajo ${ }^{14}$.

Es así como la incorporación de la categoría jurídica de la nulidad-inexistencia de los actos jurisdiccionales al derecho chileno no parece ser impertinente ni ilusoria (C), fundamentada sobre la construcción histórica de la teoría de este tipo de actos, que la ha admitido desde hace milenios (A) y sobre el espacio discreto pero indesmentible que le ha consagrado el derecho continental comparado (B).

\footnotetext{
7 Véase, v. gr., Berger (1953) p. 602; Gaffiot, voz nullus.

8 Bocksang (2010) pp. 67-80.

9 Bocksang (2010) pp. 117-127.

10 Bocksang (2006) in totum. Prevenimos, entonces, que cuando en este artículo se haga mención al vocablo nulidad, este apuntará a su sentido técnico de inexistencia jurídica; exceptuados los casos en que se transcriban normas o instituciones que utilicen el término nulidad en el sentido derivado de anulabilidad -lo que ocurre, por ejemplo, con el llamado recurso de nulidad del artículo 372 del Código Procesal Penal- y los casos en que se aluda a la "nulidad", entre comillas, para designar lo que en realidad es una situación de anulabilidad. También designarán a la nulidad, en su sentido técnico de inexistencia jurídica, expresiones en que, para favorecer la comprensión del texto, se ha empleado una fórmula compuesta, como "nulidad-inexistencia".

11 Ex multis, Bocksang (2005) in totum; Soto (2000) in totum.

12 V. gr., Соцомво (1997) t. II, p. 434; Gallo (1983) p. 124. Otras posiciones propugnan que la nulidad "sobrevive" a la cosa juzgada, lo que parece abiertamente contradictorio con la naturaleza de esta última institución; véase, v. gr., Besso (1996) p. 318.

13 V. gr., Satta (1956) pp. 341-342.

14 Bocksang (2013) sección 3.2.
} 


\section{A. LOS FUNDAMENTOS HISTÓRICOS DE LA RECEPCIÓN DE LA NULIDAD- INEXISTENCIA DE LOS ACTOS JURISDICCIONALES}

La aplicación de la nulidad stricto sensu a los actos jurisdiccionales dista muchísimo de ser una innovación contemporánea. En efecto, el hecho de que su rol se encuentre hoy en día bastante restringido se desprende de la evolución del derecho a partir del reforzamiento del poder político-gubernativo de fines de la Edad Media (2), movimiento que tiende a ocultar el auge de que gozó la nulidad-inexistencia en épocas anteriores, desde el derecho romano hasta las Partidas (1).

\section{LA INTRODUCCIÓN ROMANÍSTICO-CANÓNICA DE LA INSTITUCIÓN}

Los primeros fundamentos de importancia referidos a la nulidad-inexistencia de los actos jurisdiccionales nos son dados por el derecho romano. En relación a ellos se encuentra la dicotomía tradicional entre los tipos de invalidez de los actos jurídicos: la nulidad, en su sentido original de inexistencia jurídica, y la anulabilidad, establecida principalmente a través de la restitutio ${ }^{15}$.

Algunos casos de nulidad presentes en el Corpus iuris civilis merecen ser mencionados, no tanto por la diversidad terminológica existente ${ }^{16}$ como por la variedad de situaciones en que esta institución era aplicable.

En primer lugar, es posible advertir casos en que la incompetencia origina la nulidad de la sentencia. El caso más notable es el del Digesto 49.1.23, en el que se establece la nulidad de una sentencia rendida por una autoridad que no detentaba potestades jurisdiccionales. Sin embargo, también resulta interesante destacar algunos casos de incompetencia ratione temporis: así, mientras en el Digesto 49.8.2 se trata de la nulidad de una sentencia pronunciada por un juez cuya designación se había verificado cuando la persona aún no estaba viva, en el Digesto 42.1 .59 se trata de la nulidad de la condena post mortem referida a un edicto perentorio.

En segundo lugar, también los vicios de procedimiento podían engendrar dicha nulidad. Los casos son variados. Particularmente elocuente es el Codex 7.45.6, en que se trata el caso en que la sentencia no era pronunciada públicamente por el juez. Pero hay otras situaciones bastante notables. Así, si la sentencia establecía el deber de prestar juramento, ella era nula en caso de no especificar las consecuencias de prestarlo o rehusarlo, de acuerdo al Codex 7.45.11. Otra situación de interés es la tratada por el Codex 7.48.1, según el cual era nula una sentencia en que el juez estatuía extra petita. Y, en fin, en el Digesto 42.1.4 -apuntando simultáneamente a los efectos de la nulidad- se sostiene la imposibilidad de calificar como condenado a aquel que lo ha sido por una sentencia nula.

Debe llamarse la atención sobre el hecho de que los vicios explicados corresponden en su totalidad a lo que se denomina hoy la legalidad externa del acto, es decir, atendiendo a aspectos de competencia o de formalidades. En efecto, durante la época del derecho ro-

15 Calamandrei (1976) pp. 23-24.

16 Calamandrei (1976) pp. 26-27. 
mano clásico el contenido de la sentencia era indiferente al análisis sobre su validez ${ }^{17}$, salvo el caso de la sentencia cuyo objeto era imposible o ininteligible ${ }^{18}$. La introducción de la nulidad de la sentencia por vicios referidos al contenido se introdujo a partir del siglo tercero $^{19}$, cuando se añadieron algunos casos de errores in iudicando y, sobre todo, la nulidad contra constitutiones ${ }^{20}$. Merece particular mención, respecto de esta última, una disposición consagrada en el Digesto 49.8.1.2, por la cual cuando una sentencia es contraria a las constituciones imperiales, no existe necesidad alguna de apelar.

La influencia del Corpus iuris civilis sobre el derecho posterior fue progresivamente creciente, llegando a manifestarse con singular energía en la configuración del Derecho Canónico, y principalmente a través del Decreto de Graciano, redactado hacia el año 1139. Dado que de este Corpus justamente fueron el Codex y el Digesto los que tuvieron la más importante influencia sobre el Decreto ${ }^{21}$, no ha de sorprender que este haya recogido la categoría de la nulidad stricto sensu referida a las sentencias ${ }^{22}$.

Las situaciones regidas por esta institución se derivan de las construcciones del Corpus Iuris Civilis. Así, por ejemplo, la incompetencia del juez es causa de nulidad de la sentencia ${ }^{23}$. En materias de procedimiento o de forma, se hallan soluciones referidas a las personas que hubieran debido participar del proceso, y por lo tanto es nula la sentencia pronunciada respecto a un ausente ${ }^{24}$, así como la sentencia de un obispo pronunciada sin la presencia de los clérigos ${ }^{25}$; también en este rubro cabe destacar que el Decreto establece derechamente la nulidad de la sentencia no escrita ${ }^{26}$. El tratamiento del contenido de la sentencia también constituyó un motivo de preocupación, siendo nula aquella sentencia que no contiene ni condena ni absolución ${ }^{27}$. Y, finalmente, también se encuentra un notable llamado a la moralidad de quienes imparten justicia: con frases lapidarias se proscribe la venta de sentencias, fijándose ipso iure su nulidad, sin necesidad de reclamación alguna ${ }^{28}$.

Por otra parte, ciertas expresiones permiten describir algunos aspectos del régimen de la nulidad en el Decreto. Algunos de ellos refuerzan perspectivas más bien doctrinarias, mientras otros se aproximan concretamente a la práctica judicial. Es así como desde el punto de vista dogmático se indica explícitamente que la nulidad de una sentencia implica que

7 Calamandrei (1976) p. 35.

18 Besso (1996) p. 35.

19 Besso (1996) p. 35.

20 Besso (1996) p. 35; Calamandrei (1976) p. 48.

21 Vetulani (1948a), in totum; Vetulani (1948b) p. 129.

22 Balbi (1990) p. 33. Remitimos, para profundizar sobre este tema, a dicha obra in totum. Véase, sobre el punto específico de la cosa juzgada, López (2004) in totum.

23 Pars II, causa II, q. 1, c. 7, \$9.

24 Pars II, causa III, q. 9, c. 2.

25 Pars II, causa XV, q. 7, c. 6.

26 Pars II, causa II, q. 1, c. 7, \$14.

27 Pars II, causa II, q. 6, [c. 41], $₫ 2$.

28 Pars II, causa II, q. 6, [c. 41], $\$ 9$. 
la cosa juzgada no se forme respecto de ella ${ }^{29}$; mientras que, en cuanto a aspectos más prácticos, se enseña que la apelación de una no sentencia no es necesaria ${ }^{30}$.

Las Decretales de 1234 recogerían varios de estos desarrollos. Destaca, en particular, el título 27 del Libro II, denominado "de sententia et re iudicata", cuyo primer capítulo preceptúa que la sentencia pronunciada contra leyes o contra cánones es insubsistente ipso iure, por lo que no es necesario apelarla; como se advierte, se trata de una prolongación del principio contra constitutiones del derecho romano. Otra situación de alcances generales es la de la nulidad de las sentencias manifiestamente injustas, contenida en el capítulo 9 del mismo título 27 y que constituye otro avance en la recepción de la categoría respecto del contenido; en términos modernos, estaríamos hablando de una especie de nulidad por violación a la proporcionalidad. Estos dos casos no son los únicos tratados en las Decretales, pero bastan para mostrar de que forma la nulidad pasaba a regir situaciones que antes no estaban contempladas por ella.

No ha de sorprender, por lo tanto, que la doctrina se hallara empeñada en precisar los alcances de la inexistencia jurídica de las sentencias judiciales. El esfuerzo más notable en este sentido fue el desarrollado por Guillaume Durand, conocido también en la forma latinizada Durandus. Dicho autor, en su Speculum de 1271, Libro II, Parte III, $\$ 8$ Iuxta, luego de destacar dogmáticamente que ha de distinguirse entre la sentencia nula ipso iure y la que es annulanda -literalmente, "la que ha de ser anulada": estamos a las puertas de la terminología moderna de anulabilidad -, enuncia valientemente una síntesis de los criterios que engendran la nulidad ipso iure de las sentencias: "Pero la sentencia se dice [ser] nula de muchos modos, a saber: en razón del juez, en razón de la jurisdicción, en razón de los litigantes, en razón del lugar, en razón del tiempo, en razón de la causa, en razón de la cantidad, en razón del modo, en razón del proceso, en razón de la manifiesta iniquidad"31. La inclusión en este texto de la "manifiesta iniquidad" ha sido calificada como original ${ }^{32}$; sin embargo, parece responder a una transfusión de lo dispuesto por las Decretales y comentado supra.

De toda la progresión anterior, extendida desde el derecho romano clásico hasta la doctrina procesalista del Medioevo, no aparece como sorprendente que el cuerpo legislativo probablemente más importante de la historia del derecho castellano, las Siete Partidas (1265), haya recogido explícitamente la categoría de la nulidad de las sentencias, enumerándose en una de sus leyes, por ejemplo, tipos de vicios que engendran dicha consecuencia ${ }^{33}$. Empero,

\footnotetext{
29 Pars II, causa II, q. 6, [c. 41], \$3.

30 Pars II, causa II, q. 6, [c. 41], $\$ 5$.

31 Durand (1612) parte segunda p. 436. El texto completo del fragmento es el siguiente: "Iuxta propositionis seriem videndum restat de sententiae impugnatione, super quo scias quod quandoque sententia est nulla ipso iure, ut iam dicam, quandoque vero annullanda, ut infra $\$$ prox. Nulla autem dicitur sententia multis modis, scilicet Ratione iudicis: Ratione iurisdictionis: Ratione litigatorum: Ratione loci: Ratione temporis: Ratione causa: Ratione quantitatis: Ratione modi: Ratione processus: Ratione manifestae iniquitatis”. La traducción es nuestra.

32 Rosвoch (2010) p. 218.

33 Partida Tercera, Título XXII, Ley XII, que en síntesis contiene expresiones referidas a sentencias dadas con usurpación de poder, incompetencia, falta de investidura, falta de emplazamiento, en lugar no apto para ello, pronunciadas en días feriados, y sentencias adversas a un menor, loco o desmemoriado sin presencia de su guardador. Otra interesante enumeración de la misma época se encuentra en el Espéculo (ca. 1255), Libro V, Título XIII, Ley XV, el que, por ejemplo incorpora los casos en que "diesen el juyzio primero e recebiesen despues las
} 
el precepto más destacable a nuestro juicio, tanto por su contenido como por su elegante elocuencia, se halla en la Partida Tercera, Título XXII, Ley I, Qué cosa es juyzio:

"[El juicio] debe ser atal, que non sea contra natura, nin contra derecho de las leyes deste nuestro libro, nin contra buenas costumbres. E contra natura seria, quando el Judgador diesse por juyzio, que alguno era fijo de otro, seyendo aquel que daua por su fijo, de mayor edad que el otro, que judgana que era su padre. E contra derecho, e contra ley seria el juyzio, en que ome libre fuesse judgado por siervo (...). E contra buenas costumbres seria el juyzio, en que mandasse el Judgador, que non fuesse ome leal a su Señor, o que matasse a otro, o si mandasse alguna muger que fiziesse maldad en su cuerpo con otri, para pagar lo que deuia. Ca en qualquier destas cosas, o en otras semejantes dellas, todo juyzio que fuesse non deue valer, nin ha nome de juyzio".

La fórmula final es notable. No solo establece la consecuencia jurídica de la infracción procesal, que es la nulidad, sino que extiende el marco de este "no ser" hasta un plano lingüístico, señalando que el resultado de un tal proceso ni siquiera merece ser llamado juicio. El tenor de esta ley, que se refiere derechamente al contenido de la sentencia, se enlaza con el concepto de "sentencia manifiestamente inicua" desarrollado por la canonística, pero al mismo tiempo la sobrepasa en detalle, al indicar los componentes de este tipo de infracción. La sola existencia de este precepto hace que las imputaciones de un "palmario casuismo" de las Partidas en materia de nulidad de las sentencias ${ }^{34}$ aparezcan como exageradas.

La audacia de las Partidas es explicable por la propia evolución del derecho español en este ámbito, pues la nulidad de las sentencias había estado presente desde el Libro de los Jueces $(654)^{35}$, cuya versión castellana, el Fuero Juzgo (1241), señalaba que "si [el juicio] es dado con tuerto, ó por miedo, ó por mandado del príncipe, mandamos que sea desfecho, é non vala nada"36. Si esta expresión parece relativamente lacónica, más se extendió respecto a la nulidad el Fuero Real de España (1255) al señalar que "pleyto que sea fecho por fuerza, ò por miedo, quel tengan preso, ò que tema muerte, ò otra pena de su cuerpo, ò deshonra, ò pérdida del haber, ò otras cosas semejables, no vala" ${ }^{37}$. Así, en las Partidas convergen, frente a la inexistencia jurídica de las sentencias, varias influencias inspiradas por un espíritu común de justicia.

\section{El DEBILITAMIENTO DE LA INSTITUCiÓN EN RAZÓN DE LA ANULABILIDAD}

Sin embargo de lo anterior, se desarrollaba paralelamente en Europa un movimiento que también tenía por objeto la regulación de la invalidez en materia procesal, y que tendería a la solución contraria; esto es, a la propugnación de la anulabilidad como consecuencia jurídica de las infracciones en este ámbito. Esta tendencia surgió por influencia del derecho

proevas", el que "non pueda conprir [cumplir] aquel contra quien lo dan en ninguna manera" y si "diese [el juicio] aquel que non oviese ningun poder de judgar, maguer ploguiese a amas las partes, e lo consentiesen".

34 Morón (1957) p. 34.

35 Libro II, Título I, ley XXVII.

36 Libro II, Título I, ley XXVII.

37 Libro I, Título XI, ley IV. 
germánico, en el cual la posibilidad de impugnar una sentencia viciada expiraba de no ser ejercida seguidamente a su pronunciamiento ${ }^{38}$. Resulta interesante constatar la existencia de opiniones que sostienen que el decaimiento de la relevancia de la nulidad va aparejada con un declive de la ciencia jurídica tras la caída del Imperio Romano de Occidente ${ }^{39}$.

Particular importancia en este aspecto tendrían las leyes lombardas, en las cuales no existía la noción de la nulidad de la sentencia, y cuya única vía de impugnación era un recurso al rey ${ }^{40}$. De la miscelánea alianza de este régimen con el derecho romano resultaría la querela nullitatis ${ }^{41}$, engendrada en el derecho estatutario italiano durante el siglo XII y que permitía impugnar vicios de procedimiento ${ }^{42}$. La querela solo podía interponerse dentro de un plazo que en algunos casos, como en el del estatuto de Padua (1285), coincidía con el correspondiente a la apelación: veinte días ${ }^{43}$. En otros casos, el plazo para recurrir las distinguía: el estatuto de Módena (1327) fijaba el de diez días para la apelación, y de treinta días para la querela nullitatis ${ }^{44}$.

El influjo de esta querela no fue menor, sobre todo en el plano sistemático, pues su denominación contribuyó al desplazamiento terminológico del término nulidad, desde la noción de inexistencia hacia la de anulabilidad ${ }^{45}$. En efecto, la querela nullitatis era un ejemplo no de nulidad, sino que de anulabilidad de las sentencias ${ }^{46}$. Así, frente a la superposición de la influencia romanística -para cuyos autores la nulidad, como se ha visto supra, era una "verdadera" nulidad-, los autores se vieron forzados a distinguir entre las nullitates insanabiles y las nullitates sanabiles ${ }^{47}$.

El desmembramiento de las categorías de invalidez de las sentencias se profundizaría aun más en Italia, en búsqueda de criterios que permitiesen distinguir los casos de inexistencia de aquellos correspondientes a la simple anulabilidad. Por ejemplo, respecto de la fuente que las animaba, se separó a las nullitates iuris naturalis, que representaban casos de nulidad, de las nullitates iuris positivi, correspondientes a la anulabilidad ${ }^{48}$.

El derecho español siguió una senda similar a la de Italia respecto a la restricción de la nulidad. Sin embargo, dado el tenor explicado de las Partidas, la variación aparece como más áspera, y se manifestó primeramente en el Ordenamiento de Alcalá (1348). En este, dos disposiciones ilustran con particular claridad el vuelco de criterio. El primero se encuentra en su Título XII, Ley I:

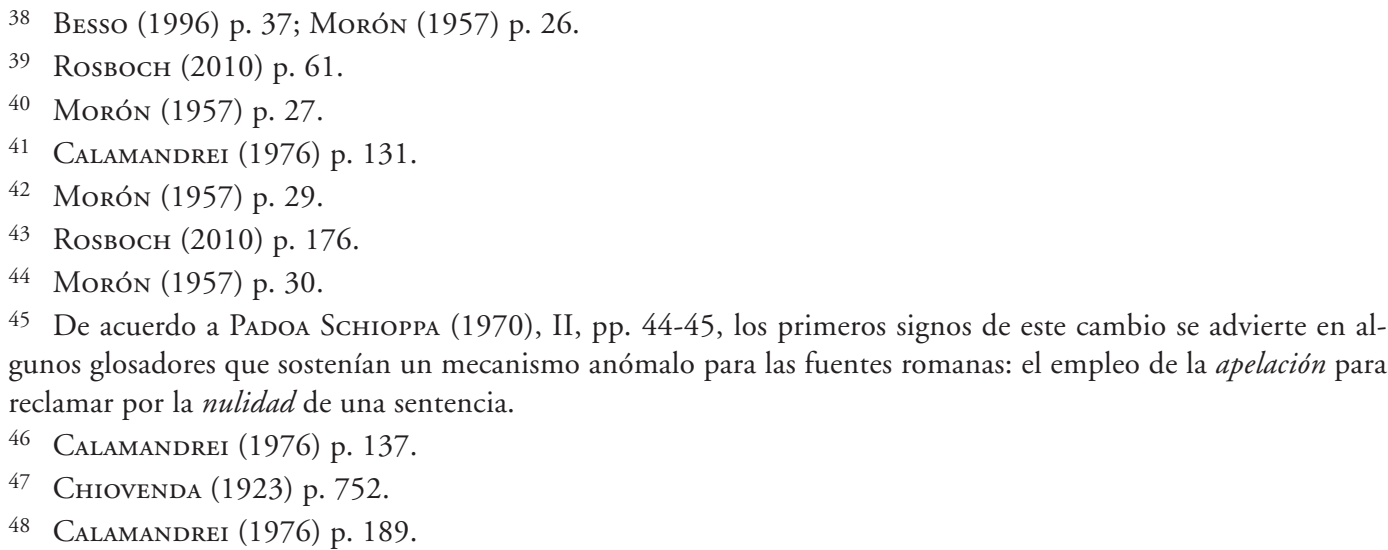


"Et por ende establecemos, que si la demanda paresciere escripta en el proceso del pleyto, maguer non sea dada por la parte en escripto, ò menguare en ella el pedimento, ò alguna de las otras cosas, que ay deben ser puestas, que son de las sotileças de los derechos, è non sea fecho en el proceso juramento de calupnia, maguer sea demandado por las partes, ò por alguna dellas, ò desfallesciendo las otras solepnidades, è substancias de la orden de los Juicios, que los derechos mandan, ò algunas dellas, conteniendose toda via en la demanda la cosa que el demandador entiende demandar, è seyendo fallada provada la verdat del fecho por el proceso del pleyto sobre que se puede dar cierta sentencia, que los Judgadores que conoscieren del pleyto, ò de los pleytos, ò los ovieren de librar, que los libren, è los judguen segunt la verdat, que en los procesos fallaren probada. Et los procesos de los pleytos, è de las sentencias, que por ellos fueren dadas, que non dejen por esta raçon de ser valederas".

El fragmento que viene de transcribirse muestra un primer golpe asestado a la nulidad de las sentencias: la restricción de su invocación respecto de la categoría de los errores in procedendo, que normalmente era tratada bajo este rubro. Pero el Ordenamiento había de reservar una segunda estocada en contra de la nulidad, aun más violenta que la anterior. Se trata de su Título XIII, Ley V:

"Si alguno allegare contra la sentencia, que es ninguna, puedalo decir fasta sesenta dias desde el dia, que fuere dada la sentencia, è si fasta los sesenta dias non lo dixiere, que non sea despues oydo sobre esta raçon; Et si en los sesenta dias dixiere que es ninguna, è fuere dada sentencia sobre ello, mandamos que contra esta sentencia non pueda ninguna de las partes decir, que es ninguna, mas puedase alçar de ella, ò suplicar; et si el Judgador fuere tal de que se non pueda alçar la parte que se sintiere agraviada, que non pueda ser puesta excebcion de nulidad dende en adelante contra las sentencias, que sobre esto fueren dadas por alçada, ò por suplicacion. Esto mandamos porque los pleytos ayan fin".

El texto de la disposición transcrita pretende derechamente eliminar la nulidad de las sentencias como categoría jurídica. Los vicios de la sentencia que se asocien con una invalidez solo permitirán una anulabilidad que no podrá ejercerse sino en el plazo breve de sesenta días, en razón de que, según esta ley, los pleitos concluyan. Ello se ve reforzado por el hecho de que la sentencia de "nulidad" no puede ser objeto, a su vez, de otro reclamo de nulidad. Como se advierte, hay un giro copernicano en torno a este tema, y que tendrá influencia en la legislación española posterior. En efecto, esta disposición será retomada hasta por la Novísima Recopilación de las leyes de España (1806), con escasos ajustes ortográficos y terminológicos ${ }^{49}$.

Sin embargo, la proscripción legislativa de la inexistencia jurídica de las sentencias no logró eliminar del todo a esta categoría en España. Ello se debe, por una parte, a la persistente influencia del derecho canónico, y por otra, a la insistencia de ciertos juristas respecto a que ciertas violaciones impedían la formación de la cosa juzgada ${ }^{50}$.

49 Libro XI, Título XVIII, Ley I.

50 Véase, en el ámbito de la América colonial, Dougnac (1996) in totum. 
Así, J. de Hevia Bolaños -jurista de fines del siglo XVI y principios del siglo XVIIexpresaba en materia civil que "es nula la sentencia dada en la causa en que haya nulidad notoria, y manifiesta, que evidente, notoria y manifiestamente consta de los mismos autos, ó de defecto de citación, ó jurisdicción: las quales nulidades, por ser perpetuas, se pueden pedir en qualquier tiempo perpetuamente, aunque de la sentencia no se haya apelado; y constando de ellas, se ha de retratar, revocar y dar por ninguna" 51 . En el punto siguiente de su Curia Philipica, Hevia Bolaños no deja ninguna duda sobre la persistencia de la nulidadinexistencia, al señalar que "las demás nulidades" son las que están sujetas al plazo de impugnación de sesenta días ${ }^{52}$.

Podría pensarse que la observación de Hevia Bolaños reflejaba un estado precario del pensamiento jurídico a inicios de la modernidad. No obstante, a principios del siglo XIX, transcurridos más de cuatrocientos años desde la entrada en vigor del Ordenamiento de Alcalá y su régimen sobre las sentencias, otros juristas seguían promoviendo la distinción entre nulidad y anulabilidad. Es el caso de R. De Dou y de Bassols, tanto en el procedimiento civil $^{53}$ como en el procedimiento criminal ${ }^{54}$. De tal modo, la nulidad-inexistencia de los actos jurisdiccionales gozaba en España de bases para subyacer silenciosamente durante épocas ulteriores.

Quepa aún un par de observaciones sobre el derecho francés, dada la influencia dogmática que ha tenido sobre otros ordenamientos, incluido el nuestro. En general, puede advertirse en Francia, a partir de la Edad Media, la misma propensión italiana y española hacia la consagración de la anulabilidad como regla general de la invalidez de las sentencias y, simultáneamente, la misma resistencia de la nulidad a ser excluida del sistema ${ }^{55}$. En efecto, la nulidad se admitía en los casos en que ella se basaba sobre las ordenanzas o las costumbres, consagrando así amplias excepciones a la tan comentada máxima "voies de nullité n'ont pas lieu en France" 56.

Esta tensión entre los dos tipos de invalidez no fue superada ni siquiera con la entrada en vigor de la Ordonnance civile de 1667. Por ejemplo, Pothier, en el Traité des obligations (1764) señala expresamente que una sentencia de objeto incierto es nula y no adquiere la autoridad de cosa juzgada ${ }^{57}$; y de igual modo declara como casos de nulidad aquellos en que el objeto de la sentencia sea imposible ${ }^{58}$, o en que el juez falle contra el texto de la ley, indicando expresamente en la sentencia que la ley no debe ser observada ${ }^{59}$. La depen-

51 Hevia Bolaños (1797), primera parte, $\$ 18, \mathrm{n}^{\circ} 13$.

52 Hevia Bolaños (1797), primera parte, $₫ 18, \mathrm{n}^{\circ} 14$.

53 De Dou y de Bassols (1802) p. 324.

54 De Dou y de Bassols (1803) p. 318.

55 Besso (1996) pp. 55-57 ; ZEARo (2008) pp. 160-162.

56 Ex multis, Argou (1694), Libro IV, capítulo XIV: “c'est pourquoi on dit par une manière de proverbe que les voyes de nullité n'ont point de lieu en France, à moins que la nullité ne soit prononcée par l'Ordonnance ou par la Coutume".

57 Pothier (1764), Parte IV, Capítulo III, artículo II, $\$ 1$ (nº 867).

58 Pothier (1764), Parte IV, Capítulo III, artículo II, $\$ 1$ (no 870).

59 Pothier (1764), Parte IV, Capítulo III, artículo II, $\$ 1$ (no 871). En esto el propio Pothier reconoce que su criterio se aparta parcialmente del sostenido por los romanos. 
dencia de este autor sobre el derecho romano en estas explicaciones no es solo conceptual, pues en su obra cita directamente los textos antiguos sobre los que se funda.

Tal como en España, en Francia intentó zanjarse el problema de la sistematización de la invalidez de las sentencias a través de una ley. En este caso se trató del Code de procédure civile (1806), principalmente a través de su artículo 1030, que prescribía que "ninguna diligencia o acto de procedimiento podrá ser declarada nula, si su nulidad no es formalmente pronunciada por la ley", inhibiendo de raíz la creatividad de los juristas para interpretar los posibles casos de nulidad ${ }^{60}$. Veremos infra, sin embargo, que la inexistencia de los actos jurisdiccionales no fue totalmente acallada en Francia por este precepto, si bien debe honestamente reconocerse que se le infligió un golpe durísimo, cuyas consecuencias se prolongan hasta nuestros días.

\section{B. LAS TENSIONES EXISTENTES RESPECTO DE LA NULIDAD-INEXISTENCIA DE LOS ACTOS JURISDICCIONALES EN EL DERECHO COMPARADO}

Sería insensato desmentir una filiación, en lo concerniente a la concepción de la nulidad de los actos jurisdiccionales, entre el desarrollo histórico que viene de explicarse y el derecho comparado contemporáneo. En efecto, los regímenes jurídicos que usualmente son tomados como referencia en derecho continental muestran una cierta reticencia a la incorporación de la nulidad stricto sensu, lo que no es sino una prolongación de la situación existente a principios del siglo XIX. Sin embargo, dicha reticencia no está exenta de tensión, pues a una sistemática un tanto adversa a la referida incorporación (1) se le opone una tópica a menudo proclive a la recepción de la nulidad (2).

\section{LA PERPLEJIDAD SISTEMÁTICA FRENTE A LA NULIDAD}

Tan natural pareciera en nuestros días el hecho de que cualquier tipo de vicio de un acto jurisdiccional se depuraría transcurrido un cierto plazo, que los ordenamientos jurídicos comparados parecieran incomodarse ante la sola posibilidad de que ciertos vicios puedan perseguirse sin límite de tiempo, entendiéndose en tales casos que la cosa juzgada no se ha constituido jamás. Esta incomodidad se desprende en buena medida del carácter sistemático de la mentalidad jurídica contemporánea. En el caso de la invalidez en derecho procesal, el "sistema" es frecuentemente cerrado con el vencimiento de los plazos para ejercer los recursos que están sujetos a ellos; la posibilidad de una imprescriptibilidad es vista como una perturbadora rara avis in terris, ajena al "sistema" comúnmente aceptado.

Así, la tendencia instintiva es a rechazar esta institución, por una cuestión de simetría o de simple comodidad, sin cuestionarse mayormente acerca de la justicia o injusticia que conllevaría en la práctica su aceptación o rechazo. Este "instinto de protección sistemática" puede ser advertido en varios planos distintos, los que merecen ser analizados brevemente.

\footnotetext{
60 Y por ello un comentarista de principios del siglo XIX como Toullier (1816) p. 645, no vaciló en sostener que "este Código no se limita a rechazar la regla establecida por Justiniano, sino que establece una diametralmente contraria”. La traducción es nuestra.
} 
1) El plano más manifiesto es el de las deficiencias en la previsión normativa de la categoría de la nulidad stricto sensu de los actos jurisdiccionales. Es cierto que no hay una plétora de disposiciones al respecto, pero la generalidad de los regímenes jurídicos consagra algún tipo de reconocimiento.

El caso más frecuente es el de la revisión de las sentencias penales, la que pretende la declaración de invalidez de una sentencia que ha incurrido en ciertos vicios específicos, sin límite de tiempo: es, por consiguiente, una eflorescencia particular del género de la nulidad-inexistencia de los actos jurisdiccionales, y prevista como tal por el StPO alemán ${ }^{61}$, el Code de procédure pénale francés ${ }^{62}$, el Code d'instruction criminelle belga ${ }^{63}$, el Code de procédure pénale suizo ${ }^{64}$, la Ley de enjuiciamiento criminal española ${ }^{65}$ y el Codice di procedura penale italiano ${ }^{66}$.

Más raro es el régimen explícito de otras situaciones como casos de nulidad-inexistencia. Un caso indiscutido y muy renombrado se encuentra en el artículo 161 del Codice di procedura civile italiano, a propósito de la nulidad por falta de firma. Dicho artículo reza de la siguiente manera: "La nulidad de las sentencias sujetas a apelación o a recurso de casación puede hacerse valer solamente en los límites y según las reglas propias a estos medios de impugnación", prescribiéndose en su inciso segundo que "esta disposición no se aplica cuando a la sentencia le falta la firma del juez" ${ }^{\prime 2}$. La doctrina ha sostenido claramente que la liberación de los límites y reglas alude al hecho de que la falta de suscripción de parte del juez impide que el acto se forme y, por consiguiente, habilita para perseguir la declaración de nulidad en cualquier tiempo ${ }^{68}$.

2) El segundo plano es el de las contradicciones terminológicas presentes en los diversos regímenes jurídicos. Para nadie es un misterio que el vocablo nulidad en nuestros días es entendido equívocamente en distintos sentidos. Puede designar a "invalidez" en general, agrupando tanto a la nulidad-inexistencia como a la anulabilidad; puede designar a "inexistencia”, que es el sentido histórico y etimológico de la palabra; y también puede designar a "anulabilidad", que es el sentido que prosaicamente se le confiere hoy, y en particular en el ámbito del derecho procesal.

Es así como el tratamiento de la nulidad stricto sensu no solo es difícil de discernir por la escasez de las disposiciones normativas que la contemplan, sino que además en razón de un empleo ambiguo de la palabra nulidad.

61 Secciones 359 y ss., y particularmente la sección 361.

62 Artículo 622.

63 Artículo 443.

64 Artículos 410 y 411.

65 Artículo 954.

66 Artículo 629.

67 La traducción es nuestra.

68 Conso (1965) p. 117; Liebman (1951) p. 107; Lugo (1967) p. 102; Pajardi (1989) p. 127; Rocco (1966), vol. II p. 272; SATta (1981) p. 244; Zanzucchi (1964) p. 442. 
En Italia tenemos un excelente ejemplo de la deformación terminológica en la categoría de la "nullità insanabile", reintroducida ${ }^{69}$ en 1955 al Codice di procedura penale de 1930, y trasegada al actual Codice, vigente desde $1989^{70}$. Dicha "nulidad" no es "insanable”, en estricto rigor, pues es purificada por la cosa juzgada ${ }^{71}$. En síntesis, se trata, a lo sumo, de una anulabilidad muy calificada, pero no del tipo imprescriptible de invalidez que es, intrínsecamente, la nulidad.

El caso de España es aun más llamativo. Mientras es indubitado que la "nulidad de pleno derecho" es imprescriptible para el Código Civil ${ }^{72}$ y para la Ley de Régimen Jurídico de las Administraciones Públicas ${ }^{73}$, la Ley 6/1985, Ley Orgánica del Poder Judicial, estableció en su artículo 238 una "nulidad de pleno derecho" que, curiosamente, se sanea ${ }^{74}$. Se trata, por lo tanto, de una anulabilidad que puede ejercerse por un tiempo más prolongado, y de ninguna manera de un caso de nulidad en sentido técnico.

En fin, en Francia hallamos un caso más próximo a la situación chilena. Dado que en derecho procesal la palabra nulidad ha pasado a designar la anulabilidad, el equívoco terminológico es soslayado a través de la invocación del término "inexistencia” para designar el tipo de invalidez imprescriptible ${ }^{75}$. Una situación análoga se da en el derecho procesal alemán, en donde suele hallarse la expresión Nichturteil (literalmente, "no sentencia") para designar el caso de la nulidad stricto sensu ${ }^{76}$.

3) Un tercer plano es el de la incomprensión de los orígenes histórico-dogmáticos de la categoría de la nulidad-inexistencia. Una cantidad considerable de análisis acerca de esta institución -sea en general, sea en especial en cuanto aplicable a los actos jurisdiccionales- se funda en concepciones bastante distorsionadas acerca de sus orígenes, características y funciones.

Analicemos un ejemplo paradigmático acerca de estos prejuicios dogmáticos: la opinión que sostiene que la razón de ser de la inexistencia sería la de un "tapa-hoyos" que opera en los casos en que la ley no prevé expresamente un caso de invalidez habiendo debido hacerlo ${ }^{77}$.

\footnotetext{
69 La "nullità insanabile" existía en el Código anterior, de 1913. Acerca de los problemas de su eliminación en el Código de 1930, véase Massari (1948) p. 253-254.

70 Artículo 179.

71 Respecto del Codice de 1930, véase, v. gr., Conso (1979) col. 265-266; De Mauro (1959) p. 191; LeOne (1968) pp. 255 y principalmente 265; Lozzi (1961) in totum. Respecto del Codice actual, véase, v. gr., CordeRo (1995) pp. 1015 y 1022-1024; Fortuna et al. (1995) pp. 313-315.

72 Ex multis, De Castro y Bravo (1971) p. 480; Díez-Picazo y Gullón (1995) p. 461; Espín (1970) p. 540.

73 Ex multis, Bocanegra (2005) p. 191; García Luengo (2002) pp. 276 ss.; González Navarro (1997) p. 483; Santamaría (1972) p. 408.

74 La propia doctrina española ha asumido que se trata técnicamente de una anulabilidad: ver, v. gr., GonZÁLez Pérez (2003) tomo II, p. 2400.

75 Respecto de la jurisdicción ordinaria, véase MAYER (2009) pp. 301-392; respecto de la jurisdicción administrativa, véase Biagini (2010) pp. 319-337. No debe olvidarse que en Francia esta institución también es designada mediante la fórmula nul et non avenu.

76 Véase, v. gr., Carnelutti (1933) p. 465; Lent (1962) p. 235.

77 Wiederkehr (1984) p. 166. Parece importante transcribir el fragmento, porque muestra de qué modo una comprensión histórico-dogmática errónea de una institución puede pervertir los razonamientos que se efectúen en torno a ella: "la notion d'inexistence... a seulement été imaginée pour pallier les lacunes des textes relatifs à
} 
Tal posición es errónea por dos motivos capitales. Históricamente porque, como ya hemos visto, la nulidad-inexistencia apareció en derecho romano como una forma de invalidez de los actos procesales que estaba asociada intrínsecamente a ciertas categorías de vicios, lo que se perpetuó en la evolución posterior del derecho occidental. No se trataba de un artificio de emergencia, sino que derivaba de un esquema plenamente consolidado en el derecho. Y dogmáticamente porque, entendida tal cual, dicha posición despedazaría la teoría de la nulidad de manera casi instantánea. Para el autor citado, "nulidad" es el equivalente a nuestra "nulidad procesal", es decir, una anulabilidad; sabemos, por otra parte, que la inexistencia es imprescriptible; en consecuencia, menuda herramienta de emergencia tendríamos si en las omisiones de casos de anulabilidad prescriptible tuviéramos que aplicar una nulidad imprescriptible: un vicio de escasa entidad impediría la formación de la cosa juzgada. Esta solución es inaceptable, y falla precisamente porque confunde la esencia de la nulidad con una de sus funciones, la de subrepción, por la cual la nulidad-inexistencia aflora, aun a falta de texto expreso, si la realidad jurídica hubiere menester de su aplicación ${ }^{78}$. Pero ella aflorará solo si, por las características de la especie, se requiriese la aplicación de la nulidad; y no si, de tales características, apareciera que la invalidez aplicable -y no prevista- fuese la anulabilidad.

Así, es fácil advertir cómo opiniones simplistas acerca de un cierto fenómeno jurídico como la inexistencia, y prescindentes de sus fundamentos históricos y dogmáticos, son capaces de deformar la reflexión en torno a ella.

4) En fin, un cuarto plano es el de las dificultades asociadas al establecimiento de un criterio delimitador entre la nulidad-inexistencia y la anulabilidad. Conviene examinar brevemente las posiciones principales en lo que concierne a este problema.

En primer lugar puede mencionarse un criterio estructural, en razón del cual todos los elementos esenciales ${ }^{79}$, intrinsecos ${ }^{80}$, indispensables ${ }^{81}$, minimos ${ }^{82}$ o constitutivos $^{83}$ deben estar presentes para que el acto se forme, aunque frecuentemente también se ha entendido que no solo el acto no se forma, sino la relación procesal en su conjunto ${ }^{84}$. No exenta de críticas en razón de una supuesta candidez dogmática ${ }^{85}$, esta posición se relaciona tanto con la presencia de los llamados presupuestos procesales ${ }^{86}$ como con la adecuación del acto específico de que se trata a un modelo 87.

la nullité. Elle n'est qu'un bouche-trou" ("la noción de inexistencia... solamente ha sido imaginada para paliar las lagunas de los textos relativos a la nulidad. Ella no es más que un tapa-hoyos"). La traducción es nuestra.

78 Bocksang (2010) pp. 538-544.

79 Fenech (1945) p. 50; Lugo (1967) p. 102, y con una perífrasis, Morón (1957) p. 118.

80 Rocco (1966) vol. II p. 271.

81 Fortuna et al. (1995) pp. 79-80 y 324, con especial énfasis en los sujetos de la relación jurídica procesal.

82 Rocco (1966) vol. II p. 272; ZanZucChi (1964) p. 442.

83 Lent (1962) p. 235; Pajardi (1989) p. 127.

84 V. gr., De Mauro (1959) p. 190; Leone (1968) p. 248; Massari (1948) p. 254; Zeppieri (1934) p. 23.

85 Cordero (1995) p. 1019. Décadas atrás ya se advertía una crítica velada a esta posición en Cordero (1957) p. 603. Empero, este autor estima que, aun cándida, esta posición es útil.

86 V. gr., Mecarelli (1984) p. 15; Santalucia (2003) pp. 175-179.

87 V. gr., Guinchard et al. (2010) p. 662, se refieren al caso de la situación que es "extraña a lo que hubiera debido hacerse". 
El segundo de los criterios es el de la gravedad de la violación ${ }^{88}$. Una violación grave engendraría la nulidad-inexistencia, mientras una violación leve engendraría la anulabilidad; y ello sin contar la posibilidad de violaciones levísimas que se consideran como irregularidades que no afectan de ningún modo la validez del acto en cuestión. A pesar de su aparente solidez, este criterio podría enfrentarse con escollos en la práctica, porque el límite entre lo grave y lo leve puede ser difuso, flexible, e incluso cambiante; ello no solo en razón de la naturaleza de la infracción, sino porque su apreciación podría variar en razón de las circunstancias en las que se hallaba inserta al ser perpetrada.

Un tercer criterio es el de la apariencia que proyecta el pretendido acto jurisdiccional. Si este gozara de una apariencia de tal, sería anulable, y no inexistente ${ }^{89}$. Por el contrario, si su apariencia no fuera de acto, estamos en frente de un caso de inexistencia. Es así como se ha sostenido que la aplicación de la nulidad-inexistencia solo se podría fundar en el hecho de que el supuesto acto no se ajuste al modelo de acto, entendido este en un sentido bastante lato ${ }^{90}$. A primera vista razonable, este criterio también origina inconvenientes, porque es perfectamente posible de que vicios de suma gravedad no aparezcan de la simple lectura de una pieza del expediente, o de la sentencia, y respecto de los cuales sería injusto permitir que el vicio no sería impugnable transcurrido un cierto plazo. Así, en la práctica judicial francesa han sido declarados inexistentes pretendidos actos no obstante presentar cabalmente una apariencia de acto jurídico ${ }^{91}$.

En cuarto lugar, puede hallarse voces que propician acoger la inexistencia en razón de la falta de idoneidad para producir los efectos que la ley le asigna al acto ${ }^{92}$. Esta visión parece más asequible y concreta que las precedentes, pero en realidad es más engañosa. Lo es porque la falta de idoneidad para producir efectos debe fundarse en algún criterio, sea el de la gravedad, el de la apariencia, las fallas estructurales, o cualquier otro; en suma, la falta de idoneidad es una fórmula meramente descriptiva, y no explicativa, dejando completamente abierto el porqué de dicha falta de idoneidad. Y también es engañosa porque define a la invalidez por vía de los efectos, posición criticable al no definir la cosa por lo que ella es, sino que por sus consecuencias, lo que puede llevar a graves equívocos en caso de que las consecuencias sean comunes pero por causas distintas. En efecto, puede existir un acto sin idoneidad alguna para producir efectos, pero en razón de circunstancias extrínsecas al acto, lo que constituye un caso de ineficacia en sentido estricto; en ese caso hay acto, pero ineficaz, no idóneo para producir ningún efecto, y sin embargo, sería totalmente erróneo sostener que se está ante un caso de inexistencia jurídica. A mayor abundamiento, y también en contra de esta posición de explicar la nulidad-inexistencia por la vía de los efectos, cabe destacarse que cualquier tipo de invalidez establece una tendencia a la ineficacia; pero es posible que se engendren efectos estables en razón de existir algún motivo, como la buena

\footnotetext{
88 Seguido, v. gr., por Liebman (1951) p. 107, Tomasin (1981) p. 870, Trigeaud (2011) p. 204.

89 Deharo (2006) p. 3308; Hernández (1995) p. 76.

90 SATta (1981) pp. 243-244.

91 MaYer (2009) p. 364.

92 Leone (1936) p. 32; Couture (1958) p. 377.
} 
fe, que ampare algún derecho o incluso la apariencia de algún derecho, incluso en el caso de la inexistencia ${ }^{93}$

En síntesis, la articulación de la inexistencia con la anulabilidad engendra dificultades, mayores o menores, para todos los ordenamientos jurídicos. Y este entuerto no parece poder resolverse eliminando a alguno de los dos tipos de invalidez, por razones que emanan directamente de la observación de la realidad. La anulabilidad no puede suprimirse, preservándose solamente la nulidad, porque la protección de la cosa juzgada exige que la regla general en materia de invalidez procesal sea una especie de invalidez caracterizada por su prescriptibilidad -que es el caso de la anulabilidad-. Y la nulidad no puede suprimirse, preservándose solamente la anulabilidad, porque la evidencia indica que cada vez que los ordenamientos jurídicos han intentado cercenar al tipo imprescriptible de invalidez -llámese inexistencia, nulidad, o como se quiera-, ella ha rebrotado con mayor o menor intensidad, por una necesidad derivada de la realidad de las $\operatorname{cosas}^{94}$. Por consiguiente, en derecho procesal parece ser inevitable una coexistencia entre nulidad-inexistencia y anulabilidad.

\section{LA INSISTENCIA TÓPICA REFERIDA A SU RECEPCIÓN}

Los obstáculos a la recepción sistemática de la nulidad de los actos jurisdiccionales, analizados en el punto anterior, no han sido de una magnitud tal que impidiese la invocación de la categoría en derecho comparado. Esta ha sido tópica, en el sentido de que la inexistencia jurídica ha sido propugnada en soluciones específicas para ciertos casos o tipos de casos.

1) Vicios relacionados con los sujetos del proceso. En primer lugar hallamos el caso de la sentencia a non iudice, esto es, pronunciada por quien no es juez. Esta categoría es una de las más ampliamente aceptadas ${ }^{95}$, y se presenta como multiforme. Puede tratarse de una sentencia pronunciada derechamente por alguien que no ha recibido investidura estatal de ningún tipo ${ }^{96}$; o bien por alguien que ha sido investido de funciones estatales, pero no jurisdiccionales ${ }^{97}$. También sería el caso del supuesto acto que ha emanado de quien aún no ha sido investido como juez ${ }^{98}$, o de quien ha cesado en el ejercicio de dichas funciones antes de la fecha de la sentencia ${ }^{99}$. Y, en fin, sería el caso de un juez que lo es en un país, pero intenta ejecutar actos en el extranjero, situación que ha sido resuelta expresamente en Italia $^{100}$.

\footnotetext{
93 Salvo que se dé alguna situación de exclusión objetiva o subjetiva de efectos, pero ello no es siempre así: véase Bocksang (2010) pp. 572-584.

94 Bocksang (2010) p. 538-544.

95 Comoghio et al. (1998) p. 357; Couture (1958) p. 377; Fortuna et al. (1995) p. 80; Cordero (1957) p. 611; Liebman (1951) p. 107; Massari (1948) p. 255; Mayer (2009) p. 390; Nuvolone (1969) p. 1408; Prieto-Castro (1985) p. 578; Pajardi (1989) p. 127.

96 Rosenberg (1955) p. 441.

97 Fenech (1945) p. 50; Lent (1962) p. 235; Leone (1968) p. 266; Mayer (2009) p. 390; RosenberG (1955) p. 441.

98 Massari (1948) p. 255.

99 Di Geronimo (2011) p. 35.

100 Di Geronimo (2011) pp. 34-35.
} 
En segundo lugar, la sentencia pronunciada en ejercicio de funciones judiciales atribuidas a otra jurisdicción. Es el caso, por ejemplo, de un juez civil que decide en materia penal, o de un juez administrativo que decide en cuestiones de exclusiva competencia de la jurisdicción ordinaria ${ }^{101}$.

En tercer lugar, la sentencia dada a intervinientes inexistentes ${ }^{102}$. Sin la existencia de las partes, resulta imposible que se constituya la relación procesal correspondiente ${ }^{103}$. En este sentido, se toma en cuenta tanto el hecho de que las partes sean existentes en abstracto, es decir, no ficticias, como que lo sean en concreto, es decir, que se encuentren vivas al momento de trabarse la relación procesal ${ }^{104}$.

En cuarto lugar, la sentencia dada a intervinientes no legitimados. Por ejemplo, si la acción que dio origen al proceso hubiere sido ejercida por un sujeto impedido legalmente para ello ${ }^{105}$, existiendo dolo o no ${ }^{106}$; y también se verificaría si en el proceso una parte hubiere sido falsamente representada por otra, situación destacada por S. Satta, por cuanto en Italia, en medio de desórdenes sociales, se llevaron procesos y fueron emitidas sentencias contra personas representadas por falsos curadores ${ }^{107}$.

En quinto lugar, la sentencia que es dada por un juez sometido a circunstancias subjetivas -es decir, del sujeto- que impedirían que se forme la relación jurídica. Por ejemplo, la sentencia dada por un juez bajo vis absoluta (fuerza física) ${ }^{108}$.

$\mathrm{Y}$ en sexto lugar, la sentencia dada por un juez en su propia causa. Esta violación, de acuerdo a E. Massari, no solo daría derecho a las partes a pedir la recusación del juez respectivo, sino que impediría la generación de la relación procesal respectiva ${ }^{109}$.

2) Vicios de forma o procedimiento. En primer lugar, la sentencia pronunciada en idioma extranjero $^{110}$. Esto habría de entenderse con la salvedad de que, eventualmente, la propia legislación permitiera el empleo de lenguas foráneas, por la naturaleza del procedimiento o por cualquier otra causa.

En segundo lugar, la sentencia dada en un proceso en que no se oyó a ambas partes, es decir, dada inaudita altera parte. Esta es la violación más flagrante de la contradictoriedad del proceso $^{111}$, de tal magnitud que hace que en realidad se trate de un no proceso ${ }^{112}$.

\footnotetext{
101 Biagini (2010) p. 323; Comoglio et al. (1998) p. 357; Leone (1968) p. 266; Massari (1948) p. 256; Rocco (1966) vol. II p. 273.

102 Fortuna et al. (1995) p. 81; Pajardi (1989) p. 127; Satta (1966) t. I, p. 537.

103 Nuvolone (1969) p. 1408.

104 Comoglio et al. (1998) p. 357.

105 Fortuna et al. (1995) p. 81; LeOne (1968) p. 266.

106 Massari (1948) p. 255.

107 SATTA (1966) t. I, p. 537.

108 Leone (1968) p. 252.

109 Massari (1948) pp. 256-257.

110 Prieto-Castro (1985) p. 578.

111 Massari (1948) p. 256; ZanZucchi (1964) p. 443.

112 Nuvolone (1969) p. 1408.
} 
En tercer lugar, la sentencia penal condenatoria que ha sido dada sobre la base de una infracción, situación que es vista frecuentemente como causal de revisión de las sentencias penales. Pueden hallarse formulaciones restrictivas, como en Francia, en que se remite a las solas declaraciones de testigos condenados posteriormente por falso testimonio ${ }^{113}$; moderadas, como en Alemania, en donde se permite la revisión al constatarse documentos falsos, testigos o peritos negligentes o falsos, y en el caso de jueces que hubieren cometido un delito en el ejercicio de sus funciones en la causa respectiva ${ }^{114}$; o amplias, como en Italia, España y Suiza, en donde la revisión es posible frente a sentencias obtenidas, en general, por influencia de una infracción penal ${ }^{115}$.

En cuarto lugar, la sentencia que no identifica a las partes o al juez. En palabras de F. Carnelutti, esto se da en razón de que faltaría un elemento de la representación más elemental del ejercicio de la jurisdicción ${ }^{116}$.

En quinto lugar, la sentencia colegial que es dada por un solo juez ${ }^{117}$. Por ejemplo, el fallo de apelación debe ser, en Francia, pronunciado por tres magistrados; la Cour de cassation ha estimado que, si es pronunciado por un solo juez, no es posible rectificarlo, apuntando por consiguiente al concepto de inexistencia jurídica ${ }^{118}$.

En sexto lugar, la sentencia oral ${ }^{119}$. Las razones de esto pueden ser múltiples: por ejemplo, la necesidad de contar institucionalmente con un acto auténtico ${ }^{120}$, o bien la imposibilidad de notificar debidamente la sentencia a falta de un quid que la represente documentalmente ${ }^{121}$.

En séptimo lugar, la sentencia carente de dispositivo ${ }^{122}$. Para que esta causal opere, la privación de dispositivo debe ser absoluta ${ }^{123}$. Si bien se ha postulado la calificación de una inexistencia material de una tal sentencia ${ }^{124}$, a nuestro juicio no existiría ningún inconveniente en propugnar, simultáneamente, su inexistencia jurídica.

En octavo lugar, la falta de firma de la sentencia. Esta situación ha sido ampliamente examinada en Italia, en razón del tenor literal del artículo 161 del Codice di procedura civile, que prescribe expresamente tal caso ${ }^{125}$, pero también ha sido propugnada en Alema-

\footnotetext{
113 Code de procédure pénale francés, art. 622, 30.

114 Strafprozessordnung, sección 359 no 1, 2 y 3. Este cuerpo normativo también permite una revisión in peius en estos casos: véase su sección 362.

115 Code de procédure pénale suizo, art. 410 inciso $1^{\circ}$, letra c); Codice di procedura penale italiano, artículo 630

d); Ley de enjuiciamiento criminal española, artículo 954 no 3.

116 Carnelutti (1933) p. 467; Rocco (1966) vol. II p. 273.

117 Fenech (1945) p. 50

118 Mayer (2009) p. 378.

119 Liebman (1951) p. 107; Rocco (1966) vol. II p. 271; ZanZucchi (1964) p. 443.

120 Mayer (2009) p. 390.

121 Carnelutti (1933) pp. 466-467.

122 Liebman (1951) p. 107; Pajardi (1989) p. 127; ZanZucchi (1964) p. 443.

123 Comoglio et al. (1998) p. 357.

124 Cordero (1957) p. 613.

125 Comoglio et al. (1998) pp. 356-357; Conso (1965) p. 117; Liebman (1951) p. 107; Lugo (1967) p. 102; Pajardi (1989) p. 127; Rocco (1966) vol. II p. 272; Satta (1981) p. 244; ZanZucchi (1964) p. 442.
} 
nia ${ }^{126}$ y en Francia; en este último país, siempre que se trate de la firma del autor del acto, y no de otro actor, como el de un ministro de fe ${ }^{127}$.

En noveno lugar, la sentencia en que se deja en blanco una parte completa. En este sentido existen sentencias de tribunales inferiores franceses, señalándose que no se trata de un vicio simple de forma, sino de un caso de inexistencia ${ }^{128}$. La particular aprensión que ha engendrado esta situación fluye probablemente de un reconocimiento de los riesgos que puede acarrear a los intervinientes.

Y en décimo lugar, la sentencia no notificada, en razón de que existiría una distorsión estructural de la sentencia ${ }^{129}$. En Alemania se ha constatado tal situación en varias subespecies: el caso de una sentencia en la que no se menciona su publicación en el acta de la sesión del tribunal; en el de una sentencia que ha sido defectuosamente notificada; y en el de una sentencia derechamente no notificada, sea a una de las partes, sea a ambas ${ }^{130}$. En Francia este caso ha sido atendido de modo más bien casuístico, habiéndose reconocido la inexistencia jurídica de la resolución en caso de falta total de notificación, así como en caso de notificación a dos demandados efectuada a través de un único documento ${ }^{131}$.

3) Vicios del contenido u objeto. En primer lugar, la sentencia que no decide. No hay sentencia si no se constituye, modifica o declara una cierta relación jurídica ${ }^{132}$.

En segundo lugar, la sentencia cuyo objeto no es ni determinado ni determinable ${ }^{133}$.

En tercer lugar, la sentencia de contenido imposible ${ }^{134}$, asimilándose a este caso el del contenido irrealizable en sede ejecutiva ${ }^{135}$. Sin embargo, S. Satta prefiere excluir esta situación del elenco de la inexistencia, arguyendo que lo que en un momento es imposible podría llegar ser posible en el futuro ${ }^{136}$.

En cuarto lugar, la sentencia incoherente o contradictoria. Puede tratarse de una incoherencia de la sentencia en si misma, en razón de que de su lectura no hay modo de establecer de qué forma se ha decidido la litis $^{137}$, pero también puede tratarse de una incoherencia de la sentencia en relación con otra, como acaece en el caso en que se admite la revisión penal por sentencias incompatibles entre sí ${ }^{138}$.

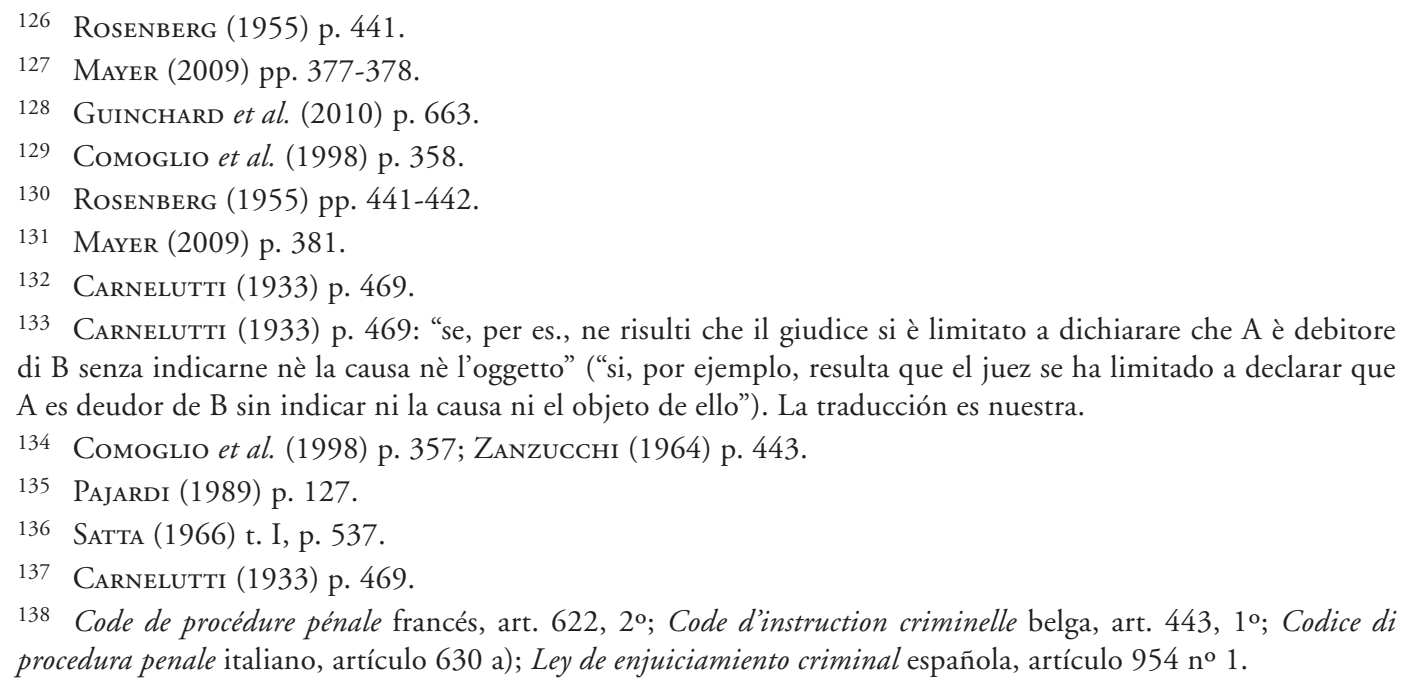


En quinto lugar, la sentencia penal condenatoria por homicidio en que se constata que la supuesta victima se encuentra viva. Se trata de una causal de revisión penal, por flagrante incompatibilidad de la sentencia con la realidad ${ }^{139}$.

$\mathrm{Y}$ en sexto lugar, la sentencia penal que deviene incompatible con hechos conocidos posteriormente. Es un caso habitual de revisión penal, fundado en que la primacía de la realidad se vería afectada de mantenerse una condena a sabiendas, por antecedentes emergidos con posterioridad, de que el sujeto es inocente ${ }^{140}$. En Alemania esta causal opera tanto para absolver al condenado como para imponer una condena menos severa ${ }^{141}$. Y en Suiza esta causal puede operar aun más ampliamente, tanto en el sentido previsto en Alemania como también in peius, pudiéndose condenar a quien había sido absuelto o aplicar una condena "sensiblemente más severa" de la que se hubiere impuesto ${ }^{142}$.

A guisa de conclusión, puede sostenerse que, a pesar de la arremetida ejecutada principalmente durante la época moderna en contra de la nulidad-inexistencia de los actos jurisdiccionales, esta categoría sigue teniendo un lugar visible en los ordenamientos jurídicos occidentales, principalmente por vía tópica. Es indudable que su presencia en la jurisprudencia es relativamente feble, pero cuenta con reafirmaciones periódicas, como la de la Corte di Cassazione italiana en 1997, que declaró explícitamente la posibilidad de las inexistencias material y jurídica de los actos procesales ${ }^{143}$. Por otra parte, la doctrina sigue preconizando su aplicación, incluso en ámbitos no generalmente reconocidos; es el caso de L. Trigeaud, quien, aun reconociendo que su alcance debería ser escaso, preconiza la recepción expresa de la inexistencia jurídica en el campo de los actos jurisdiccionales de derecho internacional público ${ }^{144}$. Es así como es de esperar que una sana conjunción entre teoría y práctica ${ }^{145}$ pueda llegar a materializar el justo ámbito de la inexistencia en el derecho continental, tal como habría de esperarse en Chile.

\section{LA NULIDAD-INEXISTENCIA DE LOS ACTOS JURISDICCIONALES EN EL DERECHO CHILENO}

La recepción chilena de esta institución, que se deriva de la fundamentación histórica y dogmática explicada supra, supone el esclarecimiento de dos puntos fundamentales: en primer lugar, la posibilidad de acogerla en nuestro ordenamiento (1), y en segundo lugar, la forma en que ha de acogerse, tanto de manera sustancial como adjetiva (2).

\footnotetext{
139 Code de procédure pénale francés, art. 622, 1; Ley de enjuiciamiento criminal española, artículo 954 no 2.

140 Code de procédure pénale francés, art. 622, 40; Code d'instruction criminelle belga, art. 443, 30; Codice di procedura penale italiano, artículo 630 c); Ley de enjuiciamiento criminal española, artículo 954 n$^{\circ} 4$.

141 Strafprozessordnung, sección 359 n 5.

142 Code de procédure pénale suizo, art. 410 , inciso $1^{\circ}$, letra a).

143 CCas, 29 de julio de 1997, n. 2053, citada por SANTALucia (2003) pp. 169-170.

144 Trigeaud (2011) pp. 204-242, y en forma sintética en p. 287.

145 Disyunción criticada, respecto de los problemas para la recuperación de la legalidad procesal, por Amodio (2004) p. 437.
} 


\section{LA POSIBILIDAD DE LA NULIDAD-INEXISTENCIA DE LOS ACTOS JURISDICCIONALES}

Ya hemos señalado en otra parte que sería ilusorio pretender que la inexistencia jurídica fuera la regla absoluta o general en materia de invalidez de los actos jurisdiccionales, pues de otra forma la institución de la cosa juzgada se vería gravemente afectada por la imprescriptibilidad que se asocia intrínsecamente a la nulidad stricto sensu ${ }^{146}$. De ahí que concordemos con A. Romero en calificar a esta institución como excepcional en el ámbito procesal ${ }^{147}$. Pero ello no significa ni mínimamente que ella haya de ser descartada sistemáticamente de nuestro orden jurídico; por el contrario, la presencia de la inexistencia jurídica de los actos jurisdiccionales es, a nuestro parecer, una institución que ha de ser integrada plenamente al Estado de Derecho chileno. Es más; no parece descabellado sostener que sin este marco de aplicación -aun menguado- de la institución en comento no pueda hablarse propiamente de la existencia cabal de un Estado de Derecho en nuestro país.

Comoquiera que sea, es menester realzar tres aspectos por los que debe considerarse que la inexistencia jurídica de los actos jurisdiccionales ya integra el régimen jurídico de Chile.

En primer lugar, una razón normativa. El artículo $7^{\text {o }}$ de la Carta Fundamental prescribe claramente en su inciso primero que "los órganos del Estado actúan válidamente" cumpliéndose ciertos requisitos. De ninguna expresión de dicho artículo puede desprenderse que el marco de aplicación del artículo $7^{\circ}$ se restringiría, como ha sido sostenido por algunos autores ${ }^{148}$, a la mera esfera administrativa. En consecuencia, el principio de legalidad establecido por el antedicho artículo abarca también el espectro de los actos jurisdiccionales ${ }^{149}$.

Existe, empero, la gran salvedad que anticipábamos líneas atrás: de admitirse a rajatabla la aplicación de la nulidad del artículo $7^{\mathrm{o}}$-que es imprescriptible- en la esfera de este tipo de actos, se negaría simultáneamente la función jurisdiccional, pues la existencia de esta implica necesariamente que el derecho "sea dicho", lo que solo ocurre cuando lo pronunciado por los tribunales de justicia no es susceptible de impugnaciones ulteriores. Como la función jurisdiccional está establecida en el artículo 76 de la Constitución, una articulación entre ambos artículos resulta ineludible: ella solo puede darse admitiendo que la regla general de la invalidez aplicable a los actos jurisdiccionales sea la anulabilidad -prescriptible, y bajo sus formas de "nulidad procesal", casación o cualesquiera otras-, quedando la nulidad del artículo $7^{\circ}$ de la Constitución circunscrita al marco de aquellas violaciones a la legalidad procesal que sean de tal gravedad que impidan la constitución de la cosa juzgada, permitiendo perseguir sin límite de tiempo -imprescriptiblemente- la declaración de nulidad correspondiente.

En segundo lugar, una razón doctrinaria. Los autores chilenos que han emprendido estudios específicos acerca de la legalidad en los procedimientos jurisdiccionales le han atribuido un marco de operación a la nulidad-inexistencia en el derecho chileno. En algunos casos la alusión a la inexistencia se limita a una enunciación dentro del catálogo de posibles

\footnotetext{
146 BocksANG (2013) apartado no 3.

147 Romero (2001) p. 784.

148 Bermúdez (2010) p. 283; Bernaschina (1949) pp. 551-552; Jara (2004) p. 91.

149 Sото (1997) pp. 348-349.
} 
consecuencias jurídicas derivadas de estas infracciones, como es el caso de J. Carrasco ${ }^{150}$; pero varios de ellos han explorado el tema con peculiaridades propias. J. Salas, por ejemplo, alude a una cierta casuística de violaciones graves ${ }^{151}$, a la que también se aproxima $\mathrm{N}$. Pozo ${ }^{152}$; J. Colombo analiza el tema sobre la base de los diversos presupuestos procesales, adoptando una posición dogmática de carácter estructural cercana a la de los autores alemanes e italianos ${ }^{153}$; en tanto que $\mathrm{M}$. Otero invoca tanto criterios estructurales ${ }^{154}$ como lógicas derivadas de la teoría de los derechos o garantías fundamentales ${ }^{155}$. Es menester volver a subrayar que ninguno de los autores precitados excluye la aplicación de la inexistencia en el ámbito procesal. Todos le atribuyen algún rol, mayor o menor.

Y, en tercer lugar, una razón jurisprudencial. Los tribunales de justicia chilenos, aún de modo muy esporádico y limitado, han declarado la inexistencia jurídica en el ámbito procesal.

En ocasiones la declaración de inexistencia corresponde a un acto endoprocedimental. Por ejemplo, en una especie de 1984 que versaba sobre la declaración de un séptimo testigo ${ }^{156}$, caso en el que la Corte de Apelaciones de Santiago declaró que dicha testimonial "no puede ser considerada, toda vez que excede al número de seis testigos por cada punto de prueba". El efecto de la infracción, según esta sentencia, "es considerar como inexistente la deposición del séptimo testigo", no viciando, sin embargo, el resto de las testimoniales. Sin embargo, es legítimo preguntarse acerca de las consecuencias que tendría la inexistencia de un acto endoprocedimental en el plano de la invalidez de la sentencia que decide el proceso. Podría eventualmente decirse que la inexistencia del primero acarrearía la inexistencia de la segunda; pero la respuesta no es tan sencilla, porque en buenas cuentas el acto endoprocedimental podría no tener influencia decisiva en el fallo o hallarse establecida alguna causal de anulabilidad respecto del vicio en cuestión. En síntesis, la inexistencia jurídica de un acto endoprocedimental podrá engendrar distintas consecuencias sobre la validez de la sentencia que decide el proceso, dependiendo de la naturaleza y características de la vulneración. En algunos casos podrá estimarse que la irregularidad era nimia y que no tiene ninguna consecuencia sobre dicha sentencia; en otros, más graves, que la irregularidad hacía anulable la sentencia, por vía de casación u otra; y en otros, gravísimos, que el vicio era tal que producía la nulidad de la sentencia impidiendo la formación de la cosa juzgada.

Pero en otras ocasiones la declaración de inexistencia se ha referido a actos que resuelven propiamente la controversia. Por una parte, en una especie de 1997, la Corte Suprema declaró la inexistencia del acto de un partidor porque el actuario del tribunal arbitral carecía del título de abogado que la ley exige. Conviene transcribir los términos de la

\footnotetext{
150 Carrasco (2011) p. 51.

151 Salas (2004) pp. 75-77.

152 Pozo (2001) pp. 66-69.

153 Соцомво (1997) t. I, pp. 149-190 respecto del "acto jurídico procesal” (amplio), y pp. 191-237 respecto del "acto procesal singular", y en t. II pp. 422-440 al exponer directamente la inexistencia; dicha posición había sido anticipada en Соцомво (1973) pp. 3-4.

154 Otero (2011) pp. 40-49 y 293-294.

155 Otero (2011) p. 295.

156 Empresa Constructora Coirón con Enami (1984).
} 
sentencia: "la falta del referido funcionario autorizante importa la inexistencia jurídica de los actos en cuestión, haciéndolos insubsanablemente inválidos” ${ }^{157}$. En todo caso, la ilustración más notable de esta categoría procede de una sentencia de 2000, en que la Corte de Apelaciones de Santiago declaró, de modo general, "que la necesidad de enmendar una sentencia injusta debe incluso sobreponerse al efecto de la cosa juzgada", tratándose dicha injusticia en la especie de un "error intolerable" derivado del ocultamiento de una prueba por parte de uno de los demandantes por cuya causa se había ordenado pagar una suma de más de seis mil millones de pesos ${ }^{158}$.

La inopia jurisprudencial es patente; sin embargo, igualmente patente es el hecho de que la inexistencia jurídica cuenta con antecedentes a lo menos precarios que habilitarían para proseguir tal línea y esclarecer su aplicación en Chile.

\section{LA APLICACIÓN DE LA NULIDAD-INEXISTENCIA DE LOS ACTOS JURISDICCIONALES}

Lo señalado en el apartado anterior permite aducir la presencia de esta institución en nuestro ordenamiento. Sin embargo, resulta evidente que lo allí expresado no nos suministra un panorama completo sobre el marco en el que ella ha de ser plasmada. Su concreción dependerá de dos movimientos que debieran producirse de modo simultáneo.

Sistemáticamente, parece ineludible que el marco de aplicación que se confiera a la nulidad tenga que coordinarse con las normas de invalidez actualmente presentes en el ordenamiento. Ello significa que las causales de anulabilidad actualmente presentes en el ordenamiento, como las de casación en la forma establecidas en el artículo 768 del Código de Procedimiento Civil, de "nulidad" del artículo 374 del Código Procesal Penal, o de "nulidad” de los artículos 477 y 478 del Código del Trabajo, deberían seguir aplicándose como tales -es decir, de anulabilidad, sujetas a un plazo de prescripción-, exceptuado el caso en que riñeren con una norma de superior jerarquía, en aplicación de los artículos $6^{\circ}$ y $7^{\circ}$ de la Constitución Política de la República.

Y metodológicamente, parece conveniente que la articulación de la nulidad-inexistencia con la anulabilidad -en sus formas de "nulidad procesal", casación o cualquiera otra- se efectúe por vía tópica, es decir, estableciéndose ciertas categorías de irregularidades que los propios tribunales de justicia vayan desvelando como correspondientes a la nulidad. En este sentido, se requerirá de un esfuerzo coordinado de la doctrina y de la jurisprudencia, a fin de darle a esta institución la mayor vitalidad posible y propiciable. No ha de descartarse una intervención del legislador en este sentido, estableciendo elencos más o menos restringidos de vicios que engendren la nulidad-inexistencia de los actos jurisdiccionales; sin embargo, ha de prevenirse que la nulidad ha demostrado ser subreptiva, en el sentido de que al pretender cercenarla de plano de un régimen jurídico, o limitarla a ciertos casos taxativamente establecidos, ella tiende a filtrarse y ser aplicada praeter o incluso contra legem. En este sentido, es quizás aconsejable -al menos en un primer período- que la propia jurisprudencia decante su marco de aplicación.

157 Alamo con Alamo (1997). Cabe resaltar que los términos de la sentencia son bastante amplios en cuanto a los actos a los que la inexistencia se aplicaría, extendiéndose también a los actos endoprocedimentales.

158 Novoa con Servicio de Impuestos Internos (2000). 
A guisa de conclusión, parece apropiado esbozar algunos elementos que sirvan de punto de partida para delimitar el ámbito de la nulidad de los actos jurisdiccionales en el derecho chileno; para ello, estimamos también de utilidad las explicaciones desarrolladas supra sobre los fundamentos históricos de esta institución y sobre su percepción en el derecho comparado. Seguiremos la estructura del marco constitucional ofrecido por el artículo $7^{\circ}$ de la Carta Fundamental.

1) Respecto del elemento de la investidura regular, no parece haber ningún obstáculo normativo para considerar que si un sujeto no ha sido investido como juez de la República, el pretendido acto jurisdiccional que emane de su actividad sea considerado como nulo, en su sentido propio de jurídicamente inexistente ${ }^{159}$.

Por ello es que el inciso primero del artículo 76 de la Constitución establece que "ni el Presidente de la República ni el Congreso pueden, en caso alguno, ejercer funciones judiciales"160. La función de dicha norma es doble: por un lado, le impide a la ley la atribución de funciones judiciales a los mentados órganos; por otro, le impide a los mentados órganos ejercerlas de hecho. Ejercidas, serían impugnables a perpetuidad, caso palmario de nulidad.

2) Respecto del elemento de la competencia, pareciera ser óbice a la invocación de la inexistencia el hecho de que la incompetencia esté tratada entre las causales de casación en el artículo 768 del Código de Procedimiento Civil. Sin embargo, a nuestro juicio, la noción de incompetencia aplicable en virtud de dicho precepto no se extiende a todas las causales de incompetencia, por lo que la inexistencia tendría un nicho operativo.

En efecto, por aplicación del artículo $6^{\circ}$ de la Constitución, ha de garantizarse el orden institucional de la República, el que reconoce la división entre causas civiles y criminales $^{161}$. Por lo mismo, no parece razonable entender que en caso de que un juez civil resolviera un asunto criminal, se purificase el vicio transcurrido un cierto plazo sin que este se impugnara: un acto tal sería jurídicamente inexistente.

Otro caso de nulidad-inexistencia previsto por la Constitución es el de un juzgamiento emanado de alguna comisión especial, según su artículo $19 \mathrm{n}^{\circ} 3$ inciso $4^{\circ}$ pues, en resumidas cuentas, parecería bastante torcido que una pseudosentencia dictada por una tal entidad se purificara transcurrido un cierto plazo.

Del Código Orgánico de Tribunales aparecen otras causas de nulidad-inexistencia. Por ejemplo, de conformidad a su artículo $4^{\circ}$ habría nulidad-inexistencia en el caso en que un tribunal de justicia usurpare funciones correspondientes a otros poderes públicos, excediendo los ámbitos establecidos en los artículos $1^{\circ}, 2^{\circ}$ y $3^{\circ}$ del mentado Código. Y, por otra

159 En este sentido, Соцомво (1973) p. 3; Соцомво (1997) t. II, pp. 429-430; Otero (2011) p. 48; Pozo (2001) pp. 66 y 69; Romero (2009) p. 31. Es probablemente la lógica que se halla tras el artículo 427 del Código del Trabajo, para el cual las audiencias desarrolladas total o parcialmente ante otra autoridad que el juez de la causa están afectas de nulidad insaneable. Aún más; como, según el mismo precepto, esta potestad es indelegable, cabría colegir que su pretendida delegación sería también inexistente.

160 Las cursivas son nuestras.

161 Artículo 76 de la Constitución; artículo 1º del Código Orgánico de Tribunales. 
parte, los artículos $5^{\circ}$ y $6^{\circ}$ pueden fundamentar la nulidad de los actos jurisdiccionales que versaren sobre asuntos promovidos fuera del territorio de la República, salvas las excepciones establecidas por la ley.

Más ampliamente, se ha entendido que de faltar la llamada "competencia absoluta" se estaría frente a un caso de inexistencia, mientras que de infringirse la "competencia relativa” de algún tribunal, se trataría de un caso de anulabilidad ${ }^{162}$. Y, en fin, también habría inexistencia en caso de que un juez abriera un proceso de oficio no estando habilitado por la ley para ello ${ }^{163}$, de conformidad al artículo $10^{\circ}$ del Código Orgánico de Tribunales.

3) Respecto de la forma, un análisis completo implicaría entrar a una casuística que excedería el marco de estas páginas, y también probablemente la imaginación de cualquier especialista. Esta causal ha sido incorporada por dos vías distintas: una conceptual y otra tópica.

En cuanto a la primera, M. Otero ha sostenido que las vulneraciones a las normas de procedimiento y al debido proceso originarían la nulidad de los pretendidos actos que emanen de tales situaciones ${ }^{164}$. En principio, dichas aseveraciones son correctas, pero con la pequeña gran salvedad de requerir de un desmenuzamiento tópico para ser aplicables, porque de su generalidad emana el riesgo de una extrema flexibilidad. Todo puede caber dentro de nociones tan amplias.

Por ello es que su invocación es estéril mientras no se particularice con vicios más concretos. Un ariete que podría servir de punto de partida es el de los principios esenciales de la justicia natural: audiatur et altera pars -óigase también a la otra parte- y nemo iudex in causa sua -nadie puede ser juez en su propia causa-. Podrá argüirse que ambos están contemplados como causal de casación; sin embargo, no parece insensato estimar que ambos principios están contenidos esencialmente en la noción de procedimiento e investigación racionales y justos del artículo 19 no 3 inciso quinto de la Constitución, primando esta por sobre las disposiciones de inferior jerarquía. De hecho, la causal de revisión penal del artículo 473 letra e) del Código Procesal Penal, derivada de la prevaricación o cohecho del juez, está ligada con la protección a los principios fundamentales de un procedimiento racional y justo, que se extravían con la perpetración de tales conductas y hacen procedente, imprescriptiblemente, la declaración de invalidez del pretendido acto.

Por último, la vía tópica ha sido sugerida en algunas situaciones. Se han planteado en la doctrina nacional, como casos de inexistencia, la sentencia desprovista de firma ${ }^{165}$, la sentencia provista de una firma falsa ${ }^{166}$, así como la sentencia que no decide ${ }^{167}$. En todo caso, otras causales podrían plantearse por la doctrina y de la jurisprudencia del examen de

162 Otero (2011) p. 49, quien no emplea el término anulabilidad, sino que invalidez, pero apuntando a un tipo de invalidez prescriptible. Contra, Соцомвo (1973) p. 3 y Pozo (2001) p. 66, quienes entienden que la inexistencia es aplicable para la falta de jurisdicción, y no de competencia.

163 Соцомво (1997) t. II, p. 432.

164 Otero (2011) pp. 293-295.

165 Pozo (2001) p. 67; Salas (2004) p. 76.

166 Pozo (2001) p. 68; Salas (2004) p. 76.

167 Pozo (2001) p. 68. 
esta institución en épocas históricas anteriores y del derecho comparado, de lo que se ha efectuado supra en este trabajo una sinopsis.

4) En fin, respecto al fondo o contenido, se trata de un elemento que, a nuestro juicio, fluye de la expresión "autoridad o derechos" del inciso segundo del artículo $7^{\text {o }}$ de la Constitución ${ }^{168}$. Las hipótesis derivadas de las normas chilenas pueden ser varias.

Por vía constitucional, la sentencia penal que violare in peius la irretroactividad de las penas establecida por el artículo $19 \mathrm{n}^{\circ} 3$ inc. $7^{\circ}$ de la Carta Fundamental. Y por vía legal, la consagración más célebre de la nulidad-inexistencia en nuestro ordenamiento: la revisión de las sentencias penales, prevista en el artículo 473 del Código Procesal Penal, cuyas causales a) a d) apuntan a problemas de fondo en razón de discrepancias intolerables para el ordenamiento jurídico entre el contenido de una sentencia y la realidad ${ }^{169}$.

Por ello no es sorprendente hallar en jurisprudencia la referencia al "error intolerable" de la sentencia de un tribunal inferior como un caso de inexistencia ${ }^{170}$. Aun aislado, este fallo no es asistemático, por cuanto se enlaza con la lógica de protección del contenido de las sentencias, presente en varias de las causales de revisión en materia penal. Y, aun aislado, este fallo no es ahistórico, pues tiene un claro vínculo con la nulidad de las sentencias manifiestamente injustas, prevista por las Decretales, así como con la nulidad por "manifiesta iniquidad” propugnada por Durandus en su Speculum; se ve con facilidad cómo, aun separadas por siete siglos de distancia, las soluciones propuestas por el Derecho para la búsqueda de la justicia pueden ser sorprendentemente próximas.

Descrito grosso modo el ámbito de aplicación de esta institución, queda por analizar el modo en que la pretensión declaratoria de nulidad de los actos jurisdiccionales puede hacerse valer en el derecho chileno. Sin perjuicio de los mecanismos que la legislación específicamente prevea -como el de la revisión de las sentencias penales, tratada en los artículos 473 a 480 del Código Procesal Penal- es menester distinguir tres vías generales básicas.

1) La vía principal está dada por la acción de nulidad de derecho público de los actos jurisdiccionales, construida sobre bases análogas a las que permitieron su consagración en el ámbito del derecho administrativo: el artículo $7^{\circ}$ de la Constitución, en cuanto establece el principio de legalidad y la nulidad de derecho público, y el artículo 19 no 3, por cuanto permite, a través de una acción, la igual protección de la ley en el ejercicio de los derechos. Ellos han de ser coordinados con su artículo 76, que, al establecer a nivel constitucional la noción de jurisdicción, restringe la aplicación de la nulidad a aquellos casos en que no se ha logrado formar la cosa juzgada, quedando sujetas las restantes situaciones a las diversas acciones de anulabilidad previstas en el ordenamiento.

\footnotetext{
168 Bocksang (2013), sección 1.2.1.c.

169 Es un caso de nulidad-inexistencia porque, de acuerdo al artículo 477 de dicho Código, se trata de un juicio "anulatorio" - rectius, declarativo de nulidad-, es decir, concerniente a la invalidez del acto en cuestión; y de acuerdo a su artículo 474 puede pedirse "en cualquier tiempo", es decir, es imprescriptible. Justamente, la inexistencia es el tipo imprescriptible de invalidez.

170 Novoa con Servicio de Impuestos Internos (2000).
} 
Aunque en varias oportunidades los tribunales de justicia han declarado que la acción de nulidad de derecho público no puede ser ejercida en contra de actos jurisdiccionales ${ }^{171}$, nos parece que tal tendencia podría -y debería- revertirse, pues su rechazo parece fundarse en el temor de transformar la totalidad de las "nulidades procesales" en casos de inexistencia jurídica, en aplicación del artículo $7^{\circ}$ de la Constitución ${ }^{172}$. Como ya hemos explicado, el riesgo no es tal; por el contrario, esta acción constitucional de nulidad de los actos jurisdiccionales no provee sino un instrumento adicional de protección de la legalidad y de los derechos de las personas cuya amplitud será controlada por la propia jurisprudencia de los tribunales de justicia, de acuerdo a las normas de la República.

2) La vía oficial está dada por la declaración de oficio de la nulidad de derecho público de los actos jurisdiccionales. Si la declaración de oficio procede de las anulabilidades procesales ${ }^{173}$, con mayor razón ella es posible respecto de la nulidad-inexistencia. Esta declaración es siempre procedente mientras el juicio se halle pendiente, en razón de que, por su propia naturaleza, sobre la nulidad-inexistencia no puede operar saneamiento ni preclusión ${ }^{174}$.

3) En fin, la vía incidental está dada por el incidente de nulidad de derecho público de los actos jurisdiccionales, el que puede interponerse en cualquier estado del proceso, hasta la vista de la causa en la Corte Suprema, tal como señala M. Otero ${ }^{175}$.

\section{CONCLUSIÓN}

1) La inexistencia jurídica de los actos jurisdiccionales no es ninguna noción innovadora. Ha existido a lo menos desde el Derecho Romano, tuvo su apogeo en la Edad Media, y se ha prolongado hasta nuestros días en derecho chileno y comparado.

2) Tampoco puede calificársele de ficticia o de artificial. Por una parte, sería extraño que un orden jurídico tan práctico como el Derecho Romano la haya consagrado, con gran prestigio, sin que cumpliese una función social de justicia; por otra parte, es lógico inferir que una institución inútil no sobreviviría a dos milenios de historia, desde la Antigüedad hasta el derecho comparado continental examinado en estas líneas.

3) Todas las bases parecen estar sentadas para una recepción más prístina de la inexistencia jurídica de los actos jurisdiccionales en el derecho chileno, por la vía de la nulidad de derecho público del artículo $7^{\text {o }}$ de la Constitución. El ordenamiento jurídico -partiendo por la Constitución misma-, la doctrina, e incluso una jurisprudencia germinal, apuntan a un tal movimiento.

4) Los temores asociados a la recepción de esta categoría no tienen, a nuestro juicio, mayor justificación, pues el propio orden jurídico nacional ponderará la extensión que estime razonable para ella, articulándola con las vías de anulabilidad actualmente existentes. Lo que sí ha de temerse es el hecho de privarnos irreflexivamente de un mecanismo de

171 V. gr., Sociedad Contractual Minera Carola con Sociedad Punta del Cobre S.A. (2002). Para un análisis de esta tendencia jurisprudencial, véase Romero (2003), in totum, y, más brevemente, Romero (2012) pp. 256-257.

172 Ver, v. gr., TAVOlaRi (2002) p. 255.

173 Código de procedimiento civil chileno, art. 83; Código procesal penal chileno, arts. 160 y 163.

174 Otero (2011) pp. 300-301.

175 Otero (2011) p. 297. 
promoción de la legalidad y de protección de los derechos so pretexto de construcciones abstractas como la seguridad jurídica u otras análogas, cuya invocación etérea para impedir un florecimiento al menos discreto de esta institución podría acaso no revelar un celo por la justicia, sino una visión peculiar acerca de la función que los órganos estatales -incluidos los de naturaleza jurisdiccional- están llamados a desempeñar en el Estado de Derecho.

\section{BIBLIOGRAFÍA CITADA}

Amodio, Ennio (2004): "Crisi della legalità processuale, filosofia della rassegnazione e autorevolezza dei giuristi”, Rivista italiana di diritto e procedura penale (2004) pp. 434-439.

Argou, Gabriel (1694): Institution au droit françois (Lyon, Molin).

Balbi, Raffaele (1990): La sentenza ingiusta nel Decretum di Graziano (Napoli, Jovene).

Berger, Adolf (1953): Encyclopedic dictionary of Roman Law (Philadelphia, The American Philosophical Society).

Bermúdez, Jorge (2008): "El principio de legalidad y la nulidad de Derecho Público en la Constitución Política. Fundamentos para la aplicación de una solución de Derecho Común”, Revista de Derecho Público vol. 70 (2008) pp. 273-285.

Bernaschina, Mario (1949): "Bases jurisprudenciales para una teoría de las nulidades administrativas", Revista del Seminario de Derecho Público de la Universidad de Chile, pp. 548-559.

Besso, Chiara (1996): La sentenza civile inesistente (Torino, Giappichelli).

Biagini, Sandrine (2010): L'inexistence en droit administratif. Contribution à l'étude de la fonction des nullités (Paris, L'Harmattan).

Bocanegra, Raúl (2005): La teoría del acto administrativo (Madrid, Iustel).

Bocksang, Gabriel (2005): "De la imprescriptibilidad de la nulidad de derecho público", Ius Publicum no 14, pp. 87-104.

Bocksang, Gabriel (2006): "De la nulidad de derecho público como inexistencia”, Ius Publicum no 16, pp. 91-116.

Bocksang, Gabriel (2010): L’inexistence juridique des actes administratifs. Essai de théorie juridique comparée: France, Chili, Espagne, Italie (Thèse, Université de Paris 1).

Bocksang, Gabriel (2013): "El ámbito de aplicación de la nulidad de derecho público", Ius Publicum, no 30, en prensas.

Calamandrei, Piero (1976): La cassazione civile: Opere giuridiche, volume sesto (Napoli, Morano).

Carnelutti, Francesco (1933): Lezioni di diritto processuale civile. Volume quarto: La funzione del processo di cognizione (Padova, CEDAM, reimpresión).

Carrasco, Jaime (2011): "La nulidad procesal como técnica protectora de los derechos y garantías de las partes en el derecho procesal chileno", Revista de derecho de la Universidad Católica del Norte, año 18 no 1 (2011) pp. 49-84.

Chiovenda, Giuseppe (1923): Principii di diritto processuale civile (Napoli, Jovene, segunda edición).

Соцомво, Juan (1973): "Algunos aspectos en torno a la ineficacia de los actos procesales en el derecho chileno", Revista de derecho procesal no 5 (1973) pp. 3-11. 
Colombo, Juan (1997): Los actos procesales (Santiago, Editorial Jurídica de Chile).

Comoglio, Luigi Paolo, Ferri, Corrado, Taruffo, Michele (1998): Lezioni sul processo civile (Bologna, Il Mulino, segunda edición).

Conso, Giovanni (1965): "Prospettive per un inquadramento delle nullità processuali civili”, Rivista trimestrale di diritto e procedura civile (1965), pp. 110-149.

Conso, Giovanni (1979): "Due apparenti anomalie del processo penale: le nullità assolute "sanabili » e le nullità relative "rilevabili d'ufficio ", La Giustizia Penale (1979), Parte Prima, col. 265-269.

Cordero, Franco (1957): "L' "inesistenza" della decisione giudiziaria (rilievi in merito ad un recente contributo giurisprudenziale all'inquadramento del problema", Rivista italiana di diritto penale (1957), pp. 602-614.

Cordero, Franco (1995): Procedura penale (Milano, Giuffrè, tercera edición).

Couture, Eduardo (1958): Fundamentos del derecho procesal civil (Buenos Aires, Depalma, tercera edición).

De Castro y Bravo, Federico (1971): El negocio jurídico (Madrid, Instituto Nacional de Estudios Jurídicos).

De Dou y de Bassols, Ramón Lázaro (1802): Instituciones de derecho público general de España, Tomo VI (Madrid, Benito García y Compañía).

De Dou y de Bassols, Ramón Lázaro (1803): Instituciones de derecho público general de España, Tomo VIII (Madrid, Benito García y Compañía).

De Mauro, Giovanni Battista (1959): Manuale di diritto processuale penale (Roma, Jandi Sapi Editori, primera edición).

Deharo, Gaëlle (2006): "La mention d'une date à laquelle la juridiction ne siège pas entraîne-t-elle l'inexistence de l'acte?", Gazette du Palais (2006), pp. 3305-3309.

Di Geronimo, Paolo (2011): La nullità degli atti nel processo penale (Milano, Giuffrè).

Díez-Picazo, Luis, Gullón, Antonio (1995): Instituciones de derecho civil (Madrid, Tecnos).

Dougnac, Antonio (1996): "La cosa juzgada en el derecho procesal del Reino de Chile", Revista de Estudios Histórico-Jurídicos (vol. 18), pp. 169-186.

Durand, Guillaume (1612): Speculum iuris (Frankfurt, Wechel, edición de 1612).

Espín, Diego (1970): "La nulidad absoluta del negocio jurídico y los efectos de la prescripción extintiva y de la usucapión”, Anuario de derecho civil, tomo XXIII (1970), pp. 519-541.

Fenech, Miguel (1945): Curso elemental de derecho procesal penal. II. Actos del proceso penal (Barcelona, Bosch).

Fortuna, Ennio, Dragone, Stefano, Fassone, Elvio, Giustozzi, Raimondo, Pignatelli, Amos (1995): Manuale pratico del nuovo processo penale (Padova, CEDAM, cuarta edición).

GAFFiot, Félix (2001): Dictionnaire latin-français (Paris, Hachette).

Gallo, Carlo Emanuele (1983): Contributo allo studio della invalidità degli atti processuali nel giudizio amministrativo (Milano, Giuffrè).

García Luengo, Javier (2002): La nulidad de pleno derecho de los actos administrativos (Madrid, Civitas).

González Navarro, Francisco (1997): Derecho administrativo español. III. El acto y el procedimiento administrativos (Pamplona, EUNSA). 
GonzÁlez Pérez, Jesús (2003): Comentarios a la ley de la jurisdicción contencioso-administrativa (Madrid, Civitas, cuarta edición).

Guinchard, Serge, Chainais, Cécile, Ferrand, Frédérique (2010): Procédure civile. Droit interne et droit de l'Union européenne (Paris, Dalloz).

Hernández, Jesús Miguel (1995): La nueva regulación de la nulidad procesal. El sistema de ineficacia de la LOPJ (Oviedo, Forum).

Hevia Bolaños, Juan de (1797): Curia Philipica (Ramón Ruiz, Madrid, reimpresión de 1797).

JARA, Jaime (2004): La nulidad de derecho público ante la doctrina y la jurisprudencia (Santiago, Libromar).

Lent, Friedrich (1962): Diritto processuale civile tedesco. Parte prima. Il procedimento di cognizione (Napoli, Morano).

Leone, Giovanni (1936): "La sentenza penale inesistente", Rivista italiana di diritto penale (1936), pp. 19-41 y 146-168.

Leone, Giovanni (1968): Diritto processuale penale (Napoli, Jovene, séptima edición).

Liebman, Enrico Tullio (1951): Lezioni di diritto processuale civile. I. Nozioni introduttive Parte generale (Milano, Giuffrè).

López, José Luis (2004): "La cosa juzgada en el derecho canónico medieval”, Revista de Estudios Histórico-Jurídicos (vol. 26), pp. 395-420.

Lozzi, Gilberto (1961): "Sui tentativi giurisprudenziali di ampliare le possibilità di sanatoria delle nullità assolute", Rivista italiana di diritto e procedura penale (1961), pp. 897-903.

Lugo, Andrea (1967): Manuale di diritto processuale civile (Milano, Giuffrè, cuarta edición).

MASSARI, Eduardo (1948): Le dottrine generali del processo penale (Napoli, Jovene).

MaYer, Lucie (2009): Actes du procès et théorie de l'acte juridique (Paris, IRJS).

Mecarelli, Franco (1984): Il provvedimento abnorme nella teoria del processo penale (Napoli, Jovene).

Morón, Manuel (1957): La nulidad en el proceso civil español (Barcelona, Editorial AHR).

Nuvolone, Pietro (1969): Trentanni di diritto e procedura penale. Studi. Volume secondo (Padova, CEDAM).

Otero, Miguel (2011): La nulidad procesal civil, penal y de derecho público (Santiago, Editorial Jurídica de Chile, segunda edición).

Padoa Schioppa, Antonio (1970): Ricerche sull'appello nel diritto intermedio (Milano, Giuffrè).

Pajardi, Piero (1989): Procedura civile. Istituzioni e lineamenti generali (Milano, Giuffrè).

Pothier, Robert-Joseph (1764): Traité des obligations (Paris, Béchet, edición Dupin de 1824).

Pozo, Nelson (2001): De las nulidades procesales (Santiago, ConoSur).

Prieto-Castro, Leonardo (1985): Tratado de derecho procesal civil. Proceso declarativo. Proceso de ejecución. I (Pamplona, Aranzadi, segunda edición).

Pugliese, Giovanni (1960): “Cosa giudicata e sentenza ingiusta nel diritto romano" en Biondi, Biondo (edit.), Conferenze romanistiche (Milano, Giuffrè), pp. 223-246.

Rocco, Ugo (1966): Trattato di diritto processuale civile. Parte generale (Torino, UTET, segunda edición). 
Romero, Alejandro (2001): "El control de oficio de los presupuestos procesales y la cosa juzgada aparente. La capacidad procesal”, Revista Chilena de Derecho vol. 28 (2001), pp. 781-789.

Romero, Alejandro (2003): "La improcedencia de la acción de nulidad de derecho público para revisar resoluciones judiciales, como precedente judicial”, Revista Chilena de Derecho vol. 30 (2003), pp. 381-385.

Romero, Alejandro (2009): Curso de derecho procesal civil. Los presupuestos procesales relativos al órgano jurisdiccional (Santiago, Editorial Jurídica de Chile).

Romero, Alejandro (2012): "La sentencia judicial como medio de prueba", Revista Chilena de Derecho vol. 39 (2012) pp. 251-276.

Rosвосн, Michele (2010): Decidere invano. I. Aspetti delle invalidità nelle sentenze medievali (Napoli, Jovene).

Rosenberg, Leo (1955): Tratado de derecho procesal civil. Tomo I (Buenos Aires, Ediciones Jurídicas Europa-América).

SALAS, Julio (2004): Los incidentes y en especial el de nulidad en el proceso civil, penal y laboral (Santiago, Editorial Jurídica de Chile).

Santalucia, Giuseppe (2003): L'abnormità dell'atto processuale penale (Padova, CEDAM).

Santamaría, Juan Alfonso (1972): La nulidad de pleno derecho de los actos administrativos (Madrid, Instituto de Estudios Administrativos).

SATTA, Salvatore (1956): "Sull'inesistenza degli atti processuali”, Rivista trimestrale di diritto e procedura civile, 1956, pp. 337-342.

SATtA, Salvatore (1966): Commentario al codice di procedura civile (Milano, Vallardi, reimpresión corregida).

SatTa, Salvatore (1981): Diritto processuale civile (Padova, CEDAM, novena edición).

Soтo, Eduardo (1997): "La nulidad de derecho público: su actualidad", Revista de Derecho de la Universidad Católica de Valparaíso, vol. 18 (1997) pp. 347-355.

Sото, Eduardo (2000): "La nulidad de derecho público de los actos estatales y su imprescriptibilidad en el derecho chileno", Ius Publicum, no 4, pp. 55-62.

Tavolari, Raúl (2002): "Comentario sobre la sentencia Villagra con Morel”, Revista de Derecho y Jurisprudencia, tomo 99 (2002), II, sección $1^{\text {a }}$, p. 255.

Tomasin, Daniel (1981): "Remarques sur la nullité des actes de procédure" en Mélanges offerts à Pierre Hébraud (Toulouse, Université de Sciences Sociales), pp. 853-874.

Trigeaud, Laurent (2011): La nullité de l'acte juridictionnel en droit international public (Limal, Anthémis).

Vetulani, Adam (1948a): "Gratien et le droit romain", Revue historique de droit français et étranger, (quatrième série, n. 24-25), pp. 11-48.

Vetulani, Adam (1948b): "Encore un mot sur le droit romain dans le Décret de Gratien", Apollinaris (n. 21), pp. 120-134.

Wiederkehr, Georges (1984): "La notion de grief et les nullités de forme dans la procédure civile”, Recueil Dalloz Sirey (1984), chronique, pp. 165-168.

Zearo, Silvère (2008): "Annulation, cassation, revision. L'anéantissement du jugement dans la procédure civile française" en Boudot, Michel y Vecchi, Paolo Maria (edit.), La théorie des nullités (Paris, Librairie Genérale de Droit et de Jurisprudence), pp. 155-184. 
Zanzucchi, Marco Tullio (1964): Diritto processuale civile. Introduzione e parte generale (Milano, Giuffrè, sexta edición).

ZePPIERI, Leone (1934): Le nullità nel processo penale (Roma, Libreria Ulpiano).

\section{NORMAS CITADAS}

Code d'instruction criminelle (Bélgica)

Code de procédure civile (Francia)

Code de procédure pénale (Francia)

Code de procédure pénale (Suiza)

Codice di procedura civile (Italia)

Codice di procedura penale (Italia)

Código de Procedimiento Civil (Chile).

Código del Trabajo (Chile)

Código Orgánico de Tribunales (Chile).

Código Procesal Penal (Chile).

Constitución Política de la República de Chile.

Corpus Iuris Civilis.

Decretales Gregorii IX.

Decretum Gratiani (Concordia Discordiantium Canonum).

Espéculo.

Fuero Juzgo.

Fuero Real de España.

Ley de enjuiciamiento criminal (España)

Ley de Régimen Jurídico de las Administraciones Públicas y del Procedimiento Administrativo Común, 30/1992 (España)

Ley Orgánica del Poder Judicial, 6/1985 (España)

Liber Iudiciorum.

Novísima Recopilación de leyes de España.

Ordenamiento de Alcalá.

Ordonnance civile de 1667 (Francia)

Las Siete Partidas.

Strafprozessordnung (Alemania).

\section{JURISPRUDENCIA CITADA}

Empresa Constructora Coirón con Enami (1984): Corte de Apelaciones de Santiago, 11 de diciembre de 1984 (apelación), Revista de Derecho y Jurisprudencia, tomo 81 (1984), II, sección 2a, pp. 141-145.

Álamo con Álamo (1997): Corte Suprema, 9 de enero de 1997 (casación forma y fondo), Revista de Derecho y Jurisprudencia, tomo 94 (1997), II, sección 1aa, pp. 6-8. 


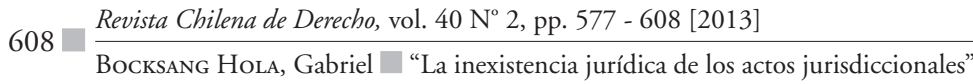

Novoa con Servicio de Impuestos Internos (2000): Corte de Apelaciones de Santiago, 24 de mayo de 2000 (apelación), Revista de Derecho y Jurisprudencia, tomo 97 (2000), II, sección 2a, pp. 16-20.

Sociedad Contractual Minera Carola con Sociedad Punta del Cobre S.A. (2002): Corte Suprema, 6 de mayo de 2002 (casación en el fondo), Revista de Derecho y Jurisprudencia, tomo 99 (2002), II, sección 1a , pp. 74-78. 